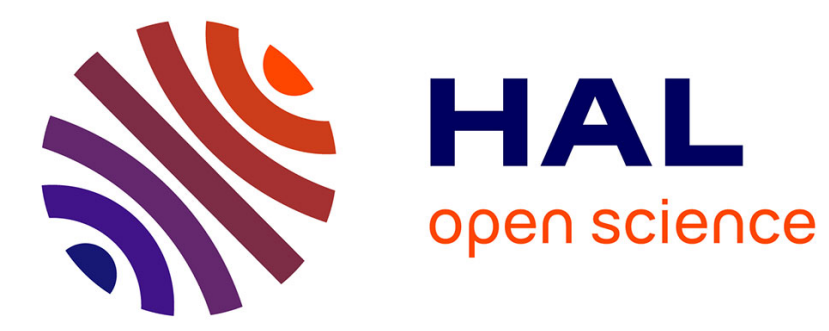

\title{
Phytoseiidae (Acari: Mesostigmata) on plants of the family Solanaceae: results of a survey in the south of France and a review of world biodiversity
}

\author{
Marie-Stéphane Tixier, Martial Douin, Serge Kreiter
}

\section{To cite this version:}

Marie-Stéphane Tixier, Martial Douin, Serge Kreiter. Phytoseiidae (Acari: Mesostigmata) on plants of the family Solanaceae: results of a survey in the south of France and a review of world biodiversity. Experimental and Applied Acarology, 2020, 28 (3), pp.357-388. 10.1007/s10493-020-00507-0 . hal02880712

\section{HAL Id: hal-02880712 \\ https://hal.inrae.fr/hal-02880712}

Submitted on 25 Jun 2020

HAL is a multi-disciplinary open access archive for the deposit and dissemination of scientific research documents, whether they are published or not. The documents may come from teaching and research institutions in France or abroad, or from public or private research centers.
L'archive ouverte pluridisciplinaire HAL, est destinée au dépôt et à la diffusion de documents scientifiques de niveau recherche, publiés ou non, émanant des établissements d'enseignement et de recherche français ou étrangers, des laboratoires publics ou privés. 


\title{
Phytoseiidae (Acari: Mesostigmata) on plants of the family Solanaceae: results of a survey in the south of France and a review of world biodiversity
}

\author{
M.-S. Tixier $^{1}$ (D) M. Douin ${ }^{1} \cdot$ S. Kreiter ${ }^{1}$
}

Received: 6 January 2020 / Accepted: 28 May 2020

(c) Springer Nature Switzerland AG 2020

\begin{abstract}
Species of the family Phytoseiidae are predators of pest mites and small insects. Their biodiversity is not equally known according to regions and supporting plants. This paper focuses on Phytoseiidae species on plants of the family Solanaceae. The Solanaceae contain many cultivated plants, for example tomato on which leaf characteristics hinder Phytoseiidae settlement and dispersal. This study presents (i) results of surveys carried out on Solanaceae in the south of France, and (ii) Phytoseiidae biodiversity on Solanaceae worldwide. Eleven species were retrieved on 20 solanaceous plants in the south of France with four main species: Euseius gallicus, Euseius stipulatus, Phytoseiulus persimilis and Typhlodromus (Anthoseius) recki. The global analysis suggests that much more species might be found enhancing sampling efforts, whatever the biogeographic region considered. Five Phytoseiidae genera concentrate the highest number of reports and species [Amblyseius, Neoseiulus, Euseius, Phytoseius and Typhlodromus (Anthoseius)]. These genera are not evolutionarily related; adaptation on Solanaceae seems to be recent, except in the Neotropical region. The latter region represents the highest number of reports, species and Solanaceae plants sampled, probably as the centre of origin of this plant family. Occurrence probabilities in biogeographic regions and plant genera are provided as a baseline for searching for new predators adapted to Solanaceae.
\end{abstract}

Keywords Predators $\cdot$ Biodiversity $\cdot$ Biogeography $\cdot$ Solanaceae $\cdot$ Mites

Electronic supplementary material The online version of this article (https://doi.org/10.1007/s1049 3-020-00507-0) contains supplementary material, which is available to authorized users.

M.-S. Tixier

marie-stephane.tixier@supagro.fr

1 CBGP, Montpellier SupAgro, INRA, CIRAD, IRD, University of Montpellier, Campus International de Baillarguet, CS 30016, 34988 Montpellier, Montferrier-sur-Lez cedex, France 


\section{Introduction}

Mites of the family Phytoseiidae are all predators and some species are important natural enemies used in biological control for limiting small insect and mite pest outbreaks (McMurtry and Croft 1997; McMurtry et al. 2013). With about 2521 valid species of Phytoseiidae described all over the world (Demite et al. 2014, 2019), this family is the best known among the order Mesostigmata due to its importance for biocontrol issues (Gerson et al. 2003). Nevertheless, Phytoseiidae fauna is not equally known all over the world (Tixier et al. 2008, 2012). Furthermore, besides the possible existence of yet undiscovered species, the occurrence of Phytoseiidae species is not exhaustively known, nor fully reported in databases. Thus, species may occur on cultivated plants but this information is not reported in a central database; in other words: these species may be candidate predators for biological control, but nobody knows. A few monographies or websites exist for specific regions or countries, e.g., the online identification key of Phytoseiidae in vineyards in Europe (Tixier et al. 2013), but this remains rare.

This paper focuses on Phytoseiidae reported on Solanaceae worldwide. The family Solanaceae contains important crops, as tomato, eggplants, pepper and potatoes. Among them, tomatoes certainly face the highest problems with mite pests: Tetranychus evansi Baker \& Pritchard, an invasive species in Africa and Europe, and two cosmopolitan species, Tetranychus urticae Koch and Aculops lycopersici (Tryon). Phytoseiid mites are used in many crops and some species are commercialised. Most of them are generalist, they can feed on mite pests but also on small insects, fungi, pollen, and plant nectar (McMurtry et al. 2013). Their occurrence is more affected by habitats (plant leaf characteristics) than by prey presence (e.g., Duso 1992; Karban et al. 1995) with clear consequences for biological control applications, as predators should thus first be adapted to the plant. On tomato (Solanum lycopersicum), because of physical barriers (such as plant trichomes) and chemical barriers (anti-feedant and/or deterrent substances in plants or sequestered in the prey's body after consuming plants), which hamper movement and development of phytoseiids (Kennedy 2003; Simmons and Gurr 2005), none of the commercialized predators is efficient enough (Zhang 2003). Pesticides are thus still used leading to resistance, environment pollution and health problems (Van Leeuwen et al. 2010). Because of the great ability of mites to adapt to environmental constraints, we hypothesise that some Phytoseiidae species or strains have adapted to Solanaceae and that such information will be useful to identify new natural enemies for biological strategy implementation.

The objectives of the present study are: (i) to present results of a survey carried out in France of phytoseiid mites on plants of the family Solanaceae; (ii) to analyse via literature compilation the Phytoseiidae fauna retrieved on Solanaceae all over the world to determine association patterns between Phytoseiidae and Solanaceae at global and biogeographic levels; and (iii) to determine how the modest survey carried out in France reflects these latter global results. The long-term applied aim is to determine which species would be interesting for biocontrol applications, relying on taxonomy and functional biodiversity (and associated ecosystemic services). 


\section{Material and methods}

\section{Surveys in France}

Surveys of phytoseiid mites were carried out in the South of France in 2014 and 2015. Mites were directly collected in fields with a fine paintbrush and put in small vials filled with ethanol. In addition, leaves were collected and mites were also recovered in the lab, using a paintbrush under a stereoscopic microscope. Mites were then mounted in Hoyer's medium and identified with a phase and interferential contrast microscope (Leica DLMB, Leica Microsystèmes SAS, Rueil Malmaison, France) $(400 \times$ magnification). The generic classification of Chant and McMurtry (2007) is used in this paper. All the voucher specimens of species collected are deposited in the mite collection of Montpellier SupAgro-INRA Acarology collection at the UMR CBGP.

\section{Literature compilation}

A database containing the Phytoseiidae species reported from Solanaceae all over the world was created using published information from 1958 (first report of Phytoseiidae on Solanaceae) to 2017. This database was constructed using the 166 publications where Phytoseiidae are reported on this plant family. In total 1241 reports are included in this analysis (encompassing the reports of the present survey). We analyse the geographic distribution of mite and plant diversity, considering the following biogeographic provinces: Nearctic (North America excluding Florida), Neotropical (South and Central America, Caribbean islands and Florida), Oriental (Taiwan, Malaysia, Philippines, India, southern China, Okinawa, Japan, Thailand, South Korea), Australasian (Australia, New Zealand, New Caledonia, Papua New Guinea, Pacific islands), Ethiopian (sub-Saharan Africa including Madagascar), and West Palaearctic (Europe, northern India, Northern Africa, Asia excluding Southern China and Okinawa). The Wallace Line (Darlington 1957) was used to separate the Oriental and Australasian provinces. We considered here the frequency of occurrence as a proxy of species abundance, as in the publications considered, the number of specimens retrieved is not always mentioned and, if mentioned, the sampling methods are different for each work leading to unsupported / representative comparisons.

\section{Statistical analysis}

Regression analyses were carried out using STATISTICA (StatSoft France 2010).

\section{Results}

\section{Surveys in France}

The 11 species found on Solanaceae are reported below. If available some information of the biology of the species is provided. Information on the known distribution of the species 
is taken from the online Phytoseiidae database (https://www.lea.esalq.usp.br/phytoseiidae/) (Demite et al. 2014, 2019).

\section{Sub-family Amblyseiinae}

\section{Amblyseius andersoni (Chant)}

Synonyms: Amblyseius britannicus (Chant), Amblyseius charui Gupta, Amblyseius potentillae (Garman), Amblyseius reflexus Denmark \& Knisley.

Specimens examined: La Garde (Var) $\left(43^{\circ} 49^{\prime} 48.404^{\prime \prime}\right.$ N, 6 $6^{\circ} 33^{\prime 25.972 " E) ~ o n ~ S o l a n u m ~}$ dulcamara (27/VII/2015, 1 q).

Biological features and occurrence on Solanaceae: Amblyseius andersoni has been described from Canada but this species is mainly reported from the Palearctic region and in some cases from the USA. This species is commercialised for biological purposes. There is no information on the origin of this species, and the countries where it has been introduced for commercial reasons. However, we presume that its occurrence in West Palearctic region is not due to commercial introductions. This species is reported from cultivated areas, especially from vineyards (Kreiter el al. 2000) and apple and peach orchards (Tixier et al. 2014). It has been reported on Solanaceae in Turkey on Solanum nigrum, S. dulcamara and Datura stramonium (Kumral and Cobanoglu 2015a, b).

\section{Euseius gallicus Kreiter \& Tixier}

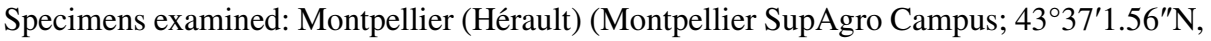
$3^{\circ} 51^{\prime} 17.135^{\prime E}$ ) on Solanum rantonnetti (11/IX/2015, 01/V/2015, 14 우), Lycium barbarum (11/IX/2015, 2 우), Capsicum sp. (29/IX/2015, 2 우); Montpellier (Jardin des Plantes; 433' $\left.50.736^{\prime \prime} \mathrm{N}, 3^{\circ} 52^{\prime} 19.284^{\prime \prime} \mathrm{E}\right)$ on Solanum pimpinellifolium (02/V/2014, 1 ㅇ); Saint Guilhem le Désert (Hérault) $\left(43^{\circ} 44^{\prime} 1.32^{\prime \prime} \mathrm{N}, 3^{\circ} 32^{\prime} 59.28^{\prime \prime} \mathrm{E}\right)$ on Solanum boraniense

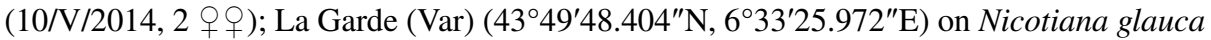
(08/VI/2015, 7 우), S. dulcamara (08/VI/2015, 1 †); Montpellier-Odysseum (Hérault) $\left(43^{\circ} 36^{\prime} 19.8^{\prime \prime} \mathrm{N}, 3^{\circ} 55^{\prime} 11.244^{\prime \prime} \mathrm{E}\right)$ on $S$. boraniense (08/IX/2016, 4 우); Firenze (Italy) $\left(43^{\circ} 49^{\prime} 1.249^{\prime \prime} \mathrm{N}, 11^{\circ} 13^{\prime} 36.251^{\prime \prime} \mathrm{E}\right)$ on $S$. boraniense (8/V/2014, 5 우).

Biological features and occurrence on Solanaceae: this species is mainly present in the West Palearctic region. It has been commercialised recently. However, natural populations are very frequent. This species has been reported once on Solanaceae in Turkey on L. barbarum (Döker et al. 2014). This is the first report of E. gallicus on other Solanaceae: $S$. rantonnetti, Capsicum sp., S. pimpinellifolium, S. boraniense, N. glauca and S. dulcamara.

\section{Euseius stipulatus (Athias-Henriot)}

Specimens examined: Corsica $\left(42^{\circ} 46^{\prime} 0 " \mathrm{~N}, 9^{\circ} 28^{\prime} 7^{\prime \prime} \mathrm{E}\right)$ on $N$. glauca (28/VI/2015, 1 ㅇ), Corsica $\left(42^{\circ} 24^{\prime} 32^{\prime \prime N}, 9^{\circ} 31^{\prime} 51^{\prime \prime E}\right)$ on Datura sp. (28/VI/2015, 1 q), Corsica (42 ${ }^{\circ} 16^{\prime} 37^{\prime \prime} \mathrm{N}$ $\left.9^{\circ} 32^{\prime} 59^{\prime \prime E}\right)$ on Capsicum annuum (29/VI/2015, 1 q), Miomo (Corsica) $\left(42^{\circ} 4437.85^{\prime \prime} \mathrm{N}\right.$, $\left.9^{\circ} 27^{\prime} 39.81^{\prime \prime E}\right)$ on Datura sp. (01/VII/2015, 2 우), Saint Guilhem-Le-Désert (Hérault) $\left(43^{\circ} 44^{\prime} 1.32^{\prime \prime} \mathrm{N}, 3^{\circ} 32^{\prime} 59.28^{\prime \prime} \mathrm{E}\right)$ on $S$. nigrum (20/IX/2014, 3 웅), on D. stramonium (20/

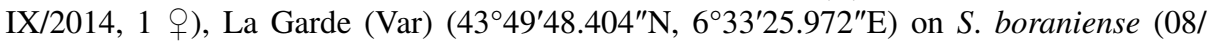
$\mathrm{VI} / 2015,5$ 우). 
Biological features and occurrence on Solanaceae: this species is mainly reported from the South of Europe and northern Africa. Natural populations are observed frequently. It has been reported from Solanaceae in Portugal (on S. nigrum), Morocco (Datura sp.) and Tunisia (S. nigrum). It is the first record of this species on N. glauca, C. annuum, D. stramonium and $S$. boraniense.

\section{Kampimodromus aberrans (Oudemans)}

Synonym: Kampimodromus vitis (Oudemans).

Specimens examined: Montpellier (Hérault) (Montpellier SupAgro Campus; $\left.43^{\circ} 37^{\prime} 1.56^{\prime \prime} \mathrm{N}, 3^{\circ} 51^{\prime} 17.135^{\prime \prime} \mathrm{E}\right)$, on $S$. rantonnetti (01/V/2015, 2 우 $)$ and Solanum lycopersicum $(01 / \mathrm{V} / 2015,1$ q).

Biological features and occurrence on Solanaceae: this species only occurs in the West Palearctic region. It is a biocontrol agent of pest mites especially in vineyards and apple orchards (Kreiter et al. 2000; Tixier et al. 2014). It was only recorded once on Solanaceae, Solanum tuberosum in Ukraine (Kolodochka and Omeri 2007). This is the first record of this species on $S$. rantonnetti and S. lycopersicum.

\section{Neoseiulus californicus (McGregor)}

Synonyms: Neoseiulus chilenensis (Dosse), Neoseiulus mungeri (McGregor), Neoseiulus wearnei (Schicha).

Specimens examined: Solanum nigrum Miomo (Corsica) (424437.85"N, 9²7'39.81"E; 27/VI/2015, 2 우), Tarascon (Bouches-du-Rhône) $\left(43^{\circ} 48^{\prime} 2.231^{\prime \prime} \mathrm{N}, 4^{\circ} 40^{\prime} 20.932^{\prime \prime} \mathrm{E}\right)$ on $S$. lycopersicum (var. H1015) (19/VIII/2015, 2 우).

Biological features and occurrence on Solanaceae: this species is widespread all over the world, certainly because of commercial biocontrol introductions. Okassa et al. (2011) showed low genetic variations between populations worldwide. This species was first described in the USA, but we do not know if it originated from this area. In Europe, natural populations of $N$. californicus are observed on uncultivated plants. In the present study, it was observed on a weed in Corsica and on tomato plantations, but no commercial releases were carried out on the plot or in the surroundings. This species has been observed on Solanaceae in Tunisia, Turkey and Egypt, mainly on S. nigrum, to a lesser extent on $S$. lycopersicum, D. stramonium and S. dulcamara (Kreiter et al. 2002; Sahraoui et al. 2012; Kumral and Cobanoglu 2015a, b).

\section{Neoseiulus cucumeris (Oudemans)}

Synonyms: Neoseiulus coprophilus (Karg), Neoseiulus thripsi (MacGill).

Specimens examined: Juvignac (Hérault) $\left(43^{\circ} 36^{\prime} 50.682^{\prime \prime} \mathrm{N}, 3^{\circ} 48^{\prime} 36.592^{\prime \prime} \mathrm{E}\right)$ on $S$. boraniense (10/V/2014, 2 q ㅇ).

Biological features and occurrence on Solanaceae: this species is mainly observed in the West Palearctic area and has been introduced in other parts of the world (Australia, USA) via commercial releases. This species is naturally observed on uncultivated plants in the West Palearctic region. It has been observed on Solanaceae in Greece on S. lycopersicum and C. annuum (Papaioannou et al. 1994; Papadoulis et al. 2009). It is the first record of this species on $S$. boraniense. 


\section{Phytoseiulus persimilis Athias-Henriot}

Synonyms: Phytoseiulus riegeli Dosse, Phytoseiulus tardi (Lombardini).

Specimens examined: Corsica $\left(42^{\circ} 21^{\prime} 6^{\prime \prime} \mathrm{N}, 9^{\circ} 24^{\prime} 16^{\prime \prime E}\right)$ on S. nigrum $(25 / \mathrm{VI} / 2015$,

2 우); Garons (Gard) $\left(43^{\circ} 46^{\prime} 10.143^{\prime \prime} \mathrm{N}, 3^{\circ} 25^{\prime} 36.643^{\prime \prime} \mathrm{E}\right)$ on S. lycopersicum (19/ VIII/2015, 26 우); Carnon (Hérault) $\left(43^{\circ} 33^{\prime} 14.906^{\prime \prime} \mathrm{N}, 4^{\circ} 026.147^{\prime \prime} \mathrm{E}\right)$ on D. stramonium (11/IX/2015, 15/VI/2014, 2 우); Montpellier (Hérault) (Montpellier SupAgro Campus; $\left.43^{\circ} 37^{\prime} 1.56^{\prime \prime} \mathrm{N}, 3^{\circ} 51^{\prime} 17.135^{\prime \prime} \mathrm{E}\right)$ on $S$. lycopersicum (16/VI/2014, 2 우); Uchaux (Vaucluse) $\left(44^{\circ} 12^{\prime} 32.78^{\prime \prime} \mathrm{N}, 4^{\circ} 48^{\prime} 3.852^{\prime \prime} \mathrm{E}\right)$ on $S$. lycopersicum $(29 / \mathrm{VI} / 2015,4$ 우우).

Biological features and occurrence on Solanaceae: this species is currently released in greenhouses to control mite pests. It is one of the most commonly found species on Solanaceae in Europe but it is difficult to determine its exact origin. Kanouh et al. (2010) studied the distribution of this species before mass releases (before 1970) and showed that among the 14 world records of $P$. persimilis before 1970, 10 were reported in the West Palaearctic area. Natural populations of $P$. persimilis are currently observed in South Europe, on non-cultivated plants and in areas where no introductions have been done (near the Mediterranean coast for instance). This species is reported on solanaceous plants in Tunisia, Israel, Turkey, Greece, Morocco, Italy and Spain. It has been collected on S. lycopersicum, Solanum villosum, Solanum melongena, S. nigrum, C. annuum, Capsicum frutescens and Solanum sodomeum (Amitai and Swirski 1978; Swirski and Amitai 1984, 1997; McMurtry and Bounfour 1989; Calvitti and Tsolakis 1992; Sekeroglu and Kazak 1993; Papaioannou et al. 1994ss; Sanchez et al. 1995; Baraja and Montalban 1996; Kreiter et al. 2002, 2010; Sahraoui et al. 2012; Tixier et al. 2016). It is the first published record of this species on D. stramonium in Europe, whereas it has been found on this plant in Peru (Guanilo et al. 2008a).

\section{Typhlodromus (Anthoseius) ilicis Athias-Henriot}

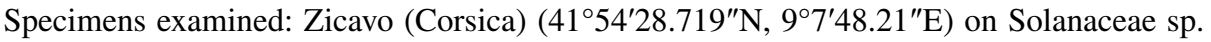
(27/VI/2015, 1 우).

Biological features and occurrence on Solanaceae: this species is only reported in the south of Europe and usually reported on plants of the genus Quercus (Moraes et al. 1986). It is the first report of this species on Solanaceae.

\section{Typhlodromus (Anthoseius) recki Wainstein}

Specimens examined: Juvignac (Hérault) $\left(43^{\circ} 36^{\prime} 50.682^{\prime \prime} \mathrm{N}, 3^{\circ} 48^{\prime} 36.592^{\prime \prime E}\right)$ on Datura sp. (03/V/2015, 1 †); Montpellier (Hérault) (Montpellier SupAgro campus; 4337'1.56"N, $\left.3^{\circ} 51^{\prime} 17.135^{\prime \prime E}\right)$ on S. melongena (29/IX/2015, 1 +), on Physalis viscosa (29/IX/2015, 4 우); Lauret (Hérault) (4350'4.389"N, 353'3.957"E) on S. tuberosum (23/VII/2015, 2 우우.

Biological features and occurrence on Solanaceae: this species is one the most reported species on solanaceous plants in the West Palearctic region, especially in Israel and Turkey (Swirski and Amitai 1997; Kumral and Cobanoglu 2015a, b). It is only observed in the West Palearctic region. It has been recorded on several cultivated and uncultivated Solanaceae: Solanum incanum, Withania somnifera, S. lycopersicum, S. melongena, S. villosum, 
S. tuberosum, $S$. nigrum, $S$. dulcamara and $D$. stramonium. This survey adds a new host plant for this species: $P$. viscosa.

\section{Discussion on the fauna found in surveys of the south of France}

Eleven Phytoseiidae species were found on 20 species of Solanaceae (Table 1). One Phytoseiidae was never reported on Solanaceae before: T. (A.) ilicis. New associations of phytoseiid species and solanaceous host plant were observed, with five and four new solanaceous hosts for E. gallicus and E. stipulatus, respectively. The species already known as common on Solanaceae in Europe have also been found in this survey, i.e., P. persimilis and T. (A.) recki.

On the 81 plants of Solanaceae surveyed (belonging to 20 species), Phytoseiidae were found on 76, suggesting that Phytoseiidae are less rare on Solanaceae than expected. It is worth to note that uncultivated Solanaceae are not highly frequent in South of France. Therefore, a low number of plants was examined for each plant species. No Phytoseiidae were observed on four Solanaceae species sampled: Datura ferox, Hyoscyamus albus, Lycium europaeum and Physalis philadelphica. However, it is impossible to decide whether this absence is due to low sampling effort or that these plants are not favourable to Phytoseiidae mites. In our own world database, only one Phytoseiidae species has been recorded (twice) on D. ferox, in Peru (Proprioseiopsis mexicanus), one Phytoseiidae was recorded once on L. europaeum (Eharius chergui) in Algeria, and no Phytoseiidae have been recorded wordwide on $H$. albus or $P$. philadelphica. Our survey results thus reflect the world situation.

Plant species with the highest probability to host Phytoseiidae were S. nigrum, S. lycopersicum (tomato), S. dulcamara and $D$. stramonium. The phytoseiid species most frequently found on the 20 Solanaceae species in our survey were E. gallicus, E. stipulatus, $P$. persimilis and $T$. (A.) recki. However, considering the number of records/plant species, $P$. persimilis seems to have a different pattern than the three other species. A high number of reports was observed on only four plant species for P. persimilis, whereas for E. gallicus, E. stipulatus and T. (A.) recki no clear preference for plants was observed. This can be explained by the feeding habits of those predators. Phytoseiulus persimilis is a dietary specialist, belonging to type 1, as defined by McMutry and Croft (1997) and McMurtry et al. (2013), whose occurrence is strongly associated with that of its prey; the three other species can feed on various kinds of food (type 3 generalist predators). Tomato was the plant on which $P$. persimilis was reported the most. Furthermore, on this plant representing the highest number of records, only two species were found: P. persimilis and N. californicus, both known to be dependent of the occurrence of its prey, as type 1 (specific) and type 2 (selective) predators, respectively. Based on these observations, two situations can be distinguished: (i) solanaceous attacked by pest mites with a high probability to be colonised by specialist predatory mites, as $P$. persimilis and $N$. californicus, and (ii) solanaceous plants bearing no or few prey, with a high probability to be colonised by generalist predatory mites. The latter species can constitute good candidates for biological control and further studies should be carried out to test their ability to control pests and to develop on Solanaceae crops. Meantime, the natural populations of P. persimilis and N. californicus herein observed on Solanaceae may have different characteristics than the ones commercially released and that often do not perform well on tomato plants. 


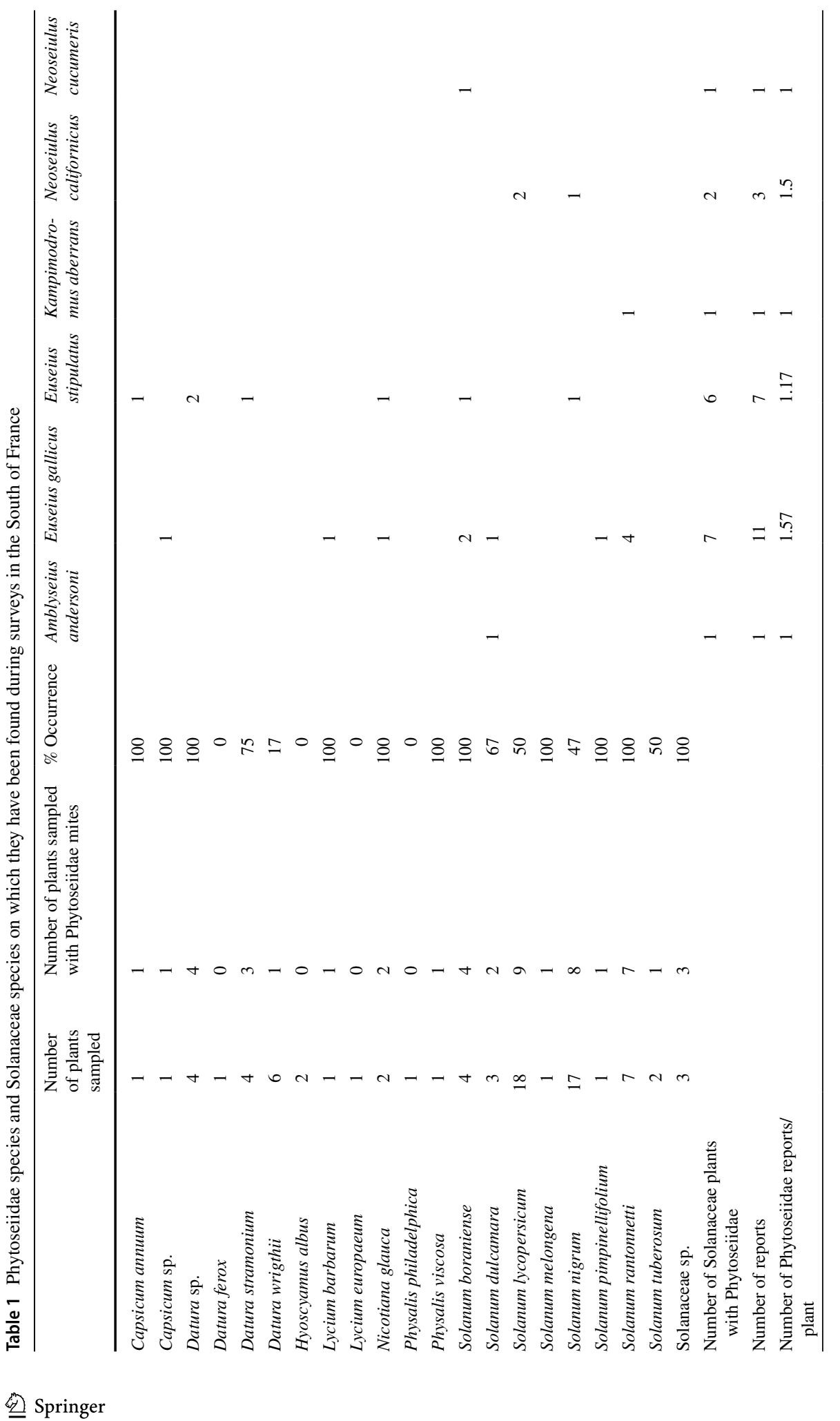




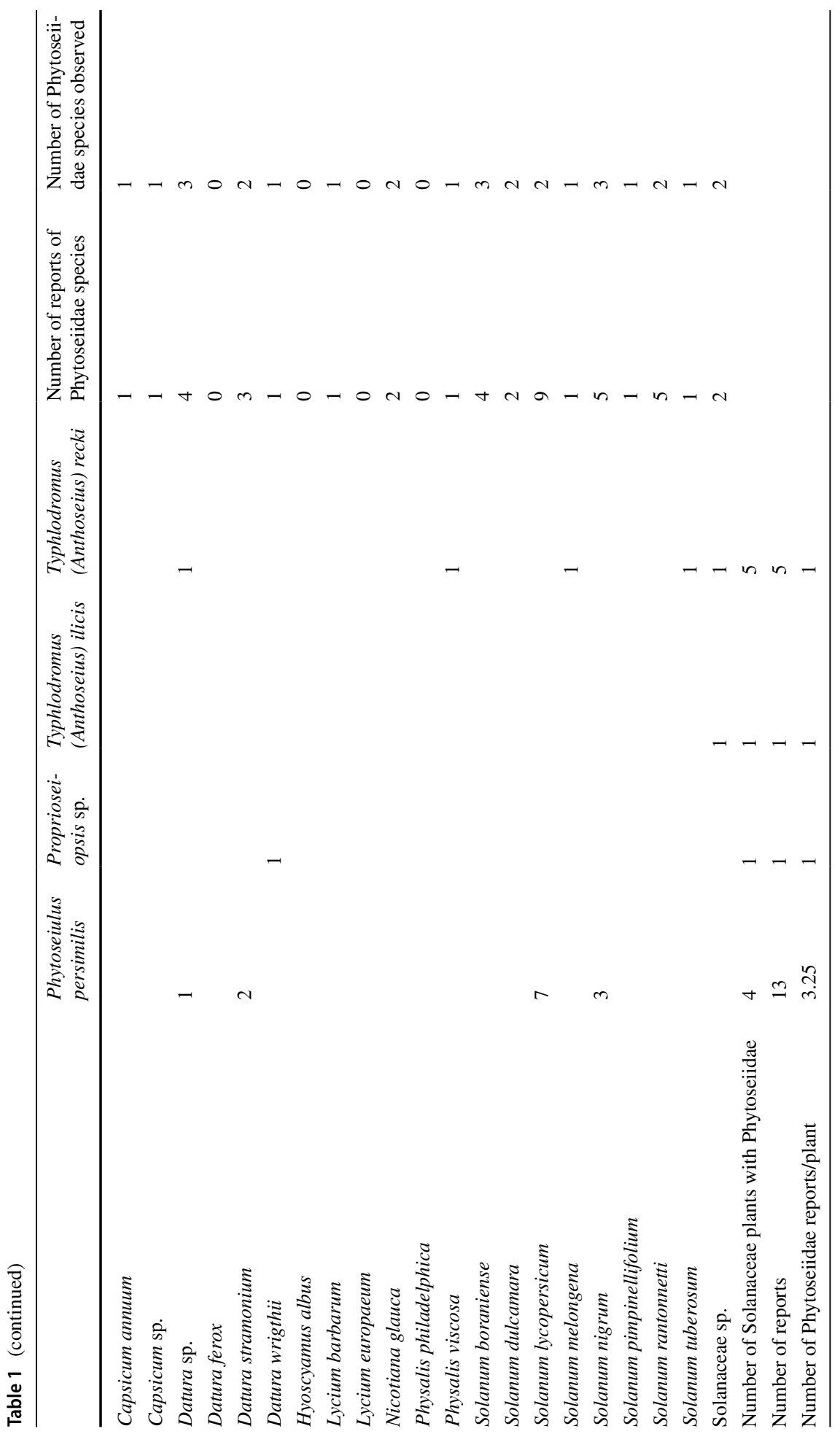




\section{Phytoseiidae diversity on Solanaceae all over the world}

Worldwide, 215 species of Phytoseiidae belonging to 37 genera were reported on 99 species of Solanaceae belonging to 16 genera (among 2521 phytoseiid species and 98 genera in total). These 215 species represent $8.5 \%$ of the diversity of Phytoseiidae and the 99 species of Solanaceae represent $3.6 \%$ of the diversity of this plant family. Species of only $40 \%$ of the genera of Phytoseiidae are recorded on only $16 \%$ of the Solanaceae genera.

The cumulative number of publications in which Phytoseiidae are reported on Solanaceae is linear through time, with a mean of 3.08 publications per year (Fig. 1). The cumulative number of reports through time shows a low progression from the 1950s to the 1990s and then a steep increase in the 2000s, essentially due to three publications amounting to 554 reports (Fiaboe et al. 2007; Guanilo et al. 2008a, b). These publications concern the Neotropical area and account for more than half of the reports in this area, suggesting that high sampling effort leads to high numbers of reports and species retrieved.

\section{Overview of Phytoseiidae diversity on Solanaceae}

The Phytoseiidae reported on Solanaceae belong to three sub-families: 143 species and 26 genera of Amblyseiinae, 45 species and 10 genera of Typhlodrominae, and 27 species and one genus of Phytoseiinae (Supplementary file 1).

The highest numbers of Phytoseiidae species found on Solanaceae are included in the genera Amblyseius (29 species), Phytoseius (27 species), Euseius (25 species), Neoseiulus (24 species) and Typhlodromus (Anthoseius) (21 species). These five genera concentrate $58 \%$ of the species reported on Solanaceae worldwide (126 species). These genera are also the most diverse within the family Phytoseiidae. On the opposite, only one species of the 14 genera Amblyseiella, Aristadromips, Chanteius, Eharius, Gynaeseius, Graminaseius, Iphiseius, Kampimodromus, Leonseius, Meyerius, Neoparaphytoseius, Phyllodromus, Ragusaseius and Tenuisternum is reported on Solanaceae (Table 2). Seven of these genera are monotypic or have only two species. It is worth to note that the four species of the genus Phytoseiulus are all reported on Solanaceae.

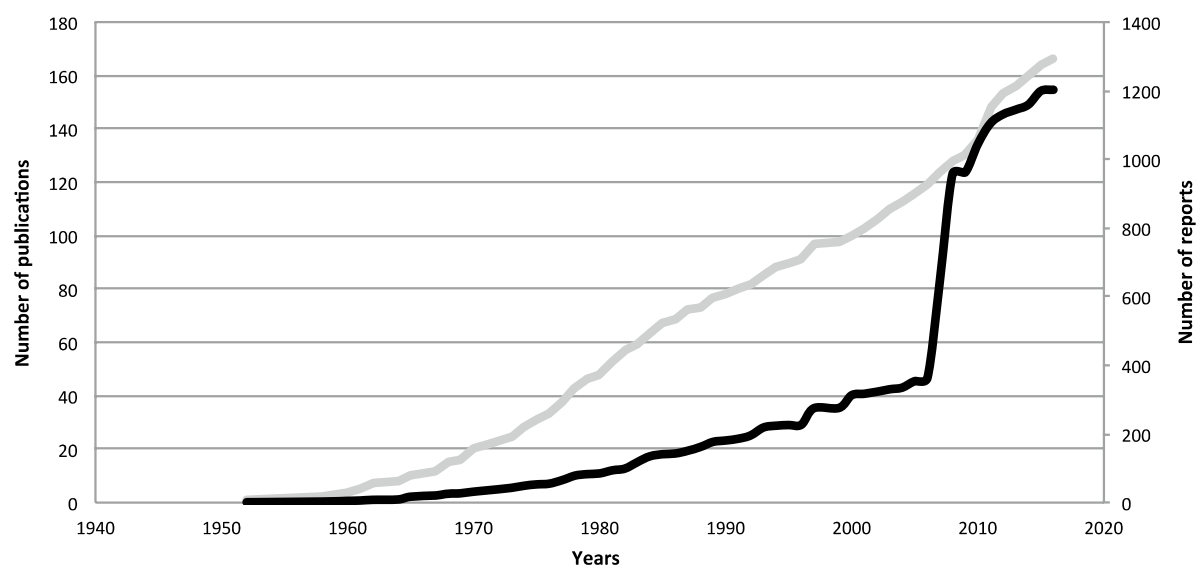

Fig. 1 Cumulative number of Phytoseiidae reports (black line) and publications (grey line) in which Phytoseiidae are mentioned on Solanaceae, through time 


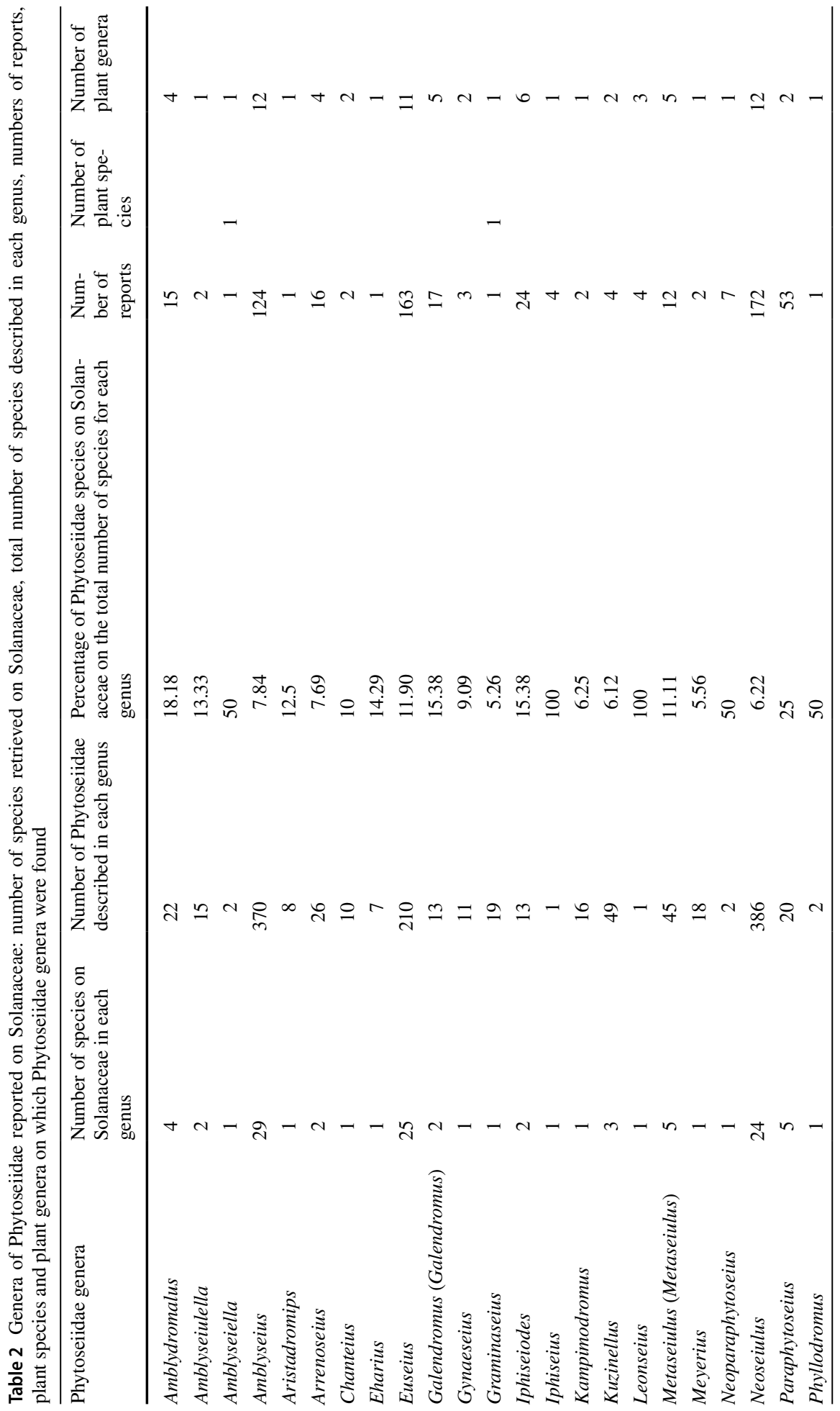




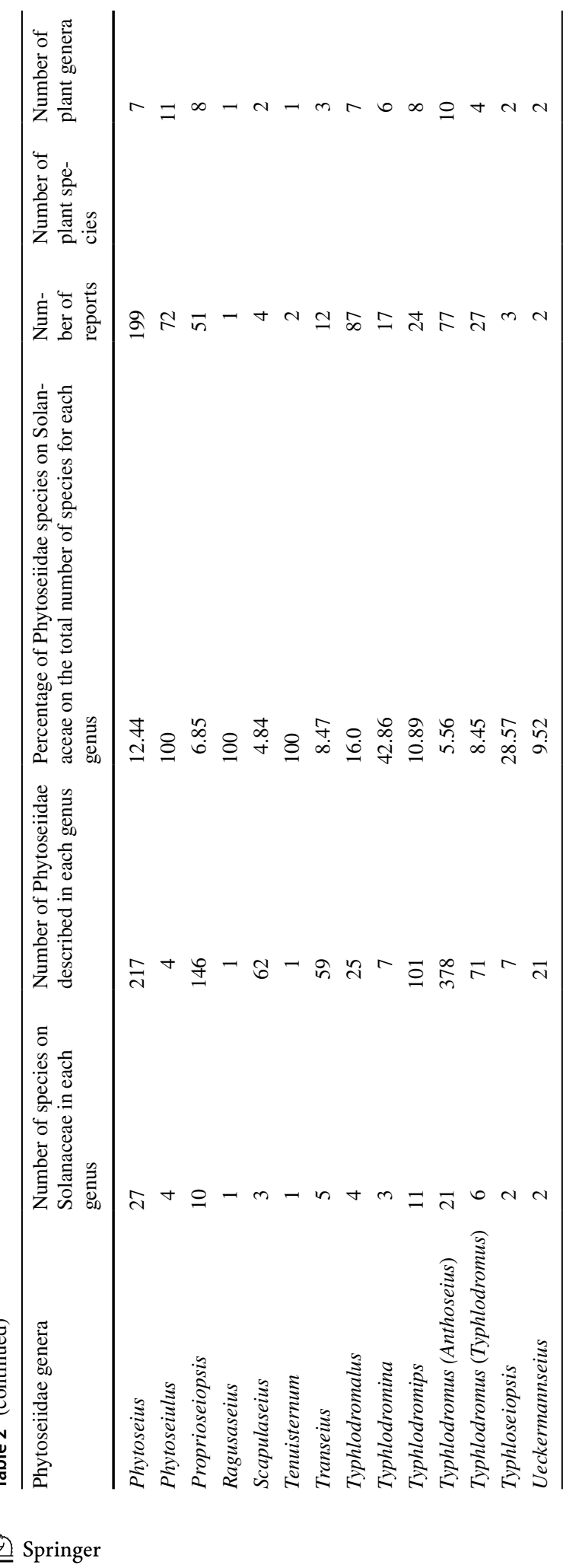


The frequency of occurrence of most Phytoseiidae species on Solanaceae is low: 97 species were recorded only once and 168 species less than $5 \times(73 \%$ of Phytoseiidae species on Solanaceae); 111 Phytoseiidae species were only collected on one Solanaceae species, 66 species on 2-5 plant species, 21 species on 6-10 plant species, and 17 species on $>11$ plant species. Among the Phytoseiidae species most frequently observed, three groups could be proposed: (1) Phytoseius guianensis De Leon is the most reported species on Solanaceae (112 reports on 19 plant species); (2) Euseius concordis (Chant) (44 reports), N. californicus (51 reports), Paraphytoseius orientalis (Narayanan, Kaur \& Ghai) (44 reports), $P$. persimilis (40 reports), Typhlodromalus aripo De Leon (44 reports) and Typhlodromalus peregrinus (Muma) (40 reports) were observed more than $40 \times$ on Solanaceae and are also reported on a high number of Solanaceae species ( $>19$ species), except $P$. orientalis which is reported on 12 plant species; (3) five Phytoseiidae species were reported between 21 and $39 \times$ : Iphiseiodes zuluagai Denmark \& Muma, Neoseiulus idaeus Denmark \& Muma, Neoseiulus tunus (De Leon), Phytoseiulus macropilis (Banks), and T. (A.) recki. The number of plant species on which these species were observed ranges between 9 and 16 .

There exists a significant logarithmic correlation between the number of reports and the number of plant species on which the Phytoseiidae species are reported $\left(\mathrm{R}^{2}=0.79\right.$, $P<0.01$ ), suggesting that the Phytoseiidae species most recorded are globally also the ones occurring on a larger number of plant species and thus more likely to be adapted to Solanaceae (Supplementary file 2). A high positive correlation was observed between the number of reports and the number of Phytoseiidae species per genus $\left(\mathrm{R}^{2}=0.82, P<0.01\right)$, suggesting that the higher the number of reports, the more likely it is to find many Phytoseiidae of a particular genus. Similarly, there is a positive linear relation between the number of Phytoseiidae species retrieved on Solanaceae and the number of species described per genus $\left(\mathrm{R}^{2}=0.87, P<0.01\right)$, suggesting that the bigger a particular genus is, the more probable it is to find species of this genus on Solanaceae (Supplementary file 2). For the latter two correlations, no saturation is observed suggesting that many more species of Phytoseiidae are to be discovered on Solanaceae when the number of surveys increases.

\section{Phytoseiidae diversity and biogeographic regions}

Phytoseidae are reported on Solanaceae in the six biogeographic regions considered (Table 3). However, 186 species of Phytoseiidae (i.e., $86 \%$ of the species reported on Solanaceae) are only reported from one region, 16 species from two, and 9 species from three regions. The most worldwide-distributed Phytoseiidae species (five regions, not reported in the Oriental region) is $P$. persimilis, certainly because of its introduction for biological control purposes. However, this species is not only reported in cultivated plants but also on wild plants, such as Datura (see below and present survey in France). Amblyseius tamatavensis Blommers is present in four regions corresponding to the ex-continent Gondwana (Neotropical, Australasian, Ethiopian and Oriental regions). These data suggest a different adaptation to Solanaceae according to the region considered. The number of Phytoseiidae species/genera/region is the highest for the Neotropical, Palearctic and Oriental region (Table 3). The highest numbers of reports and species is observed in the Neotropical region (804 reports: $67 \%$ of the reports in the world; 102 species: $47 \%$ of the species reported on Solanaceae). It is also in this region that the ratio 'number of reports per Phytoseiidae species' is the highest (six species recorded more than $30 \times:$ E. concordis, $N$. californicus, $P$. orientalis, $P$. guianensis, $T$. aripo and $T$. peregrinus). 


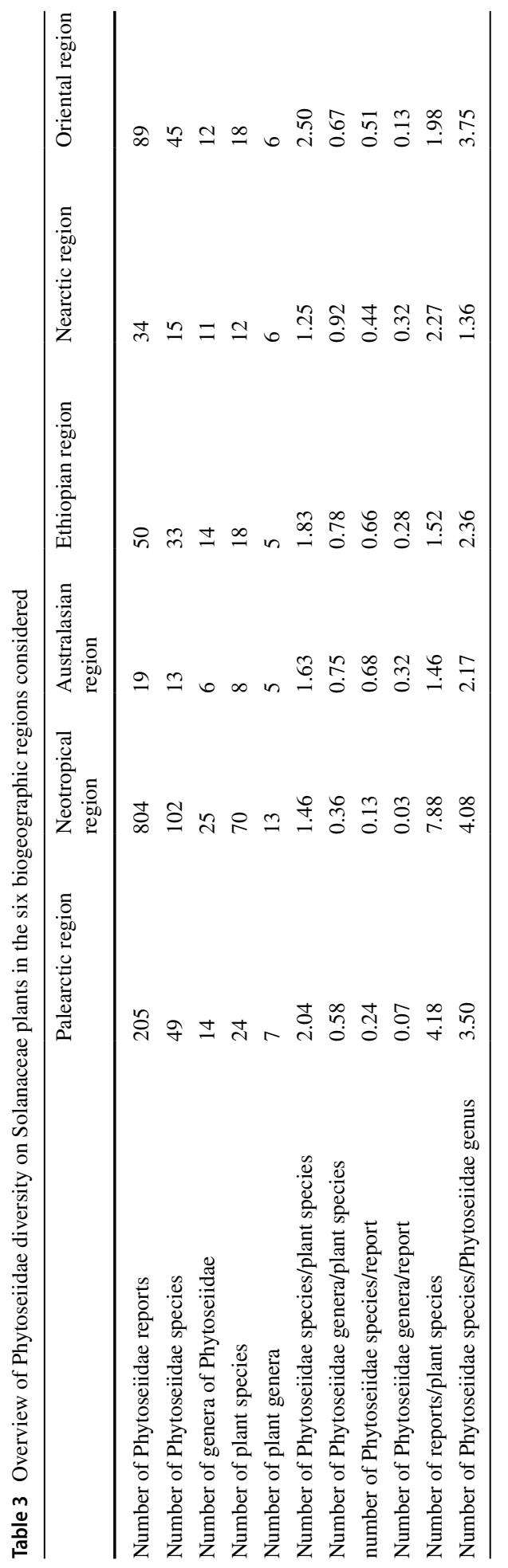


The high number of reports and diversity in the Neotropical region is probably due to the high diversity of species of this family in South America (area of origin of Solanaceae) (Olmstead, 2013). This region records the highest number of Solanaceae species (71) and genera (13) where Phytoseiidae are reported. The next regions where Phytoseiidae were the most reported are the Palearctic (205 reports, 49 species) and the Oriental ( 89 reports, 45 species) areas. In the Palearctic region, only a few Phytoseiidae species prevail: $P$. persimilis (27 reports), T. (A.) recki (26 reports) and Typhlodromus (Typhlodromus) athiasae Porath \& Swirski (19 reports). On the opposite, in the Oriental region many species are reported a few times and the highest number of records is low: $5 \times$ for Neoseiulus longispinosus (Evans), Paraphytoseius bhadrakaliensis (Gupta) and Phytoseius kapuri Gupta. In the other three regions, the number of reports and Phytoseiidae species on Solanaceae is much lower (Australasian: 19 reports, 13 species; Ethiopian region: 50 reports, 33 species; Nearctic region: 34 reports, 15 species). The highest recorded species in the Nearctic region is T. peregrinus (seven reports), in the Australasian region it is Transeius montdorensis (Schicha) (four records) and in the Ethiopian region Phytoseius amba Pritchard \& Baker (four reports).

The number of Phytoseiidae species/plant species/region is highest in the Palearctic and Oriental regions whereas this index is quite low in the Neotropical region. This suggests that in the two former regions it is more probable to find more than two species on a single Solanaceae species than in the Neotropical region, certainly because of the higher Solanaceae diversity and may be because of a 'specialisation' in the Neotropical region. The highest values of number of phytoseiid genera/plant/region are found in the Oriental, Ethiopian, Australasian and Nearctic region, suggesting that in these regions it is more probable to find more genera on Solanaceae than in the Neotropical and Palearctic regions.

The number of Phytoseiidae species/report/region and the number of Phytoseiidae genera/report/region are highest for the Australasian, Ethiopian, Nearctic and Oriental regions and the values are quite low for Neotropical and Palearctic areas. This suggests that the probability to find a newly reported species/genus when carrying out surveys is higher in the former regions probably because these regions were little surveyed.

The number of reports/plant species/region is highest for the Neotropical region and (somewhat lower for) the Palearctic region. This suggests that in these two areas the probability to recurrently find Phytoseiidae species on Solanaceae is the highest.

A positive linear relation was observed between the number of reports and the number of species/genus for the Palearctic $\left(\mathrm{R}^{2}=0.79, P<0.01\right)$, Neotropical $\left(\mathrm{R}^{2}=0.61, P<0.01\right)$, Ethiopian $\left(\mathrm{R}^{2}=0.76, P<0.01\right)$ and Oriental regions $\left(\mathrm{R}^{2}=0.92, P<0.01\right)$ (Supplementary file 3). For the Australasian $\left(\mathrm{R}^{2}=0.10, P=0.54\right)$ and Nearctic $\left(\mathrm{R}^{2}=0.09, P=0.83\right)$ regions the correlation was not significant, probably because of the low number of data.

Twenty Phytoseiidae genera are only reported from one region; they usually correspond to endemic genera of a region and to monotypic genera or genera containing a low number of species. It is interesting to note the high number of reports for the genera Arrenoseius and Galendromus (Galendromus) in the Neotropical region. Four genera are reported in the six biogeographic regions (Neoseiulus, Euseius, Amblyseius and Phytoseius). Some patterns could be drawn for each region considering the percentage of reports/ region/ genera and the percentage of species/region/genera (>10\%) (Table 4).

In the Palearctic region, the highest percentage of reports is observed for the genera Euseius, Neoseiulus, Phytoseiulus, Typhlodromus (Anthoseius) and Typhlodromus (Typhlodromus) and the highest percentage of species was also observed for those genera, except for Phytoseiulus (Table 5). In the Neotropical region, the highest percentage of reports is observed for the genera Euseius, Neoseiulus, Typhlodromalus and Phytoseius and the 


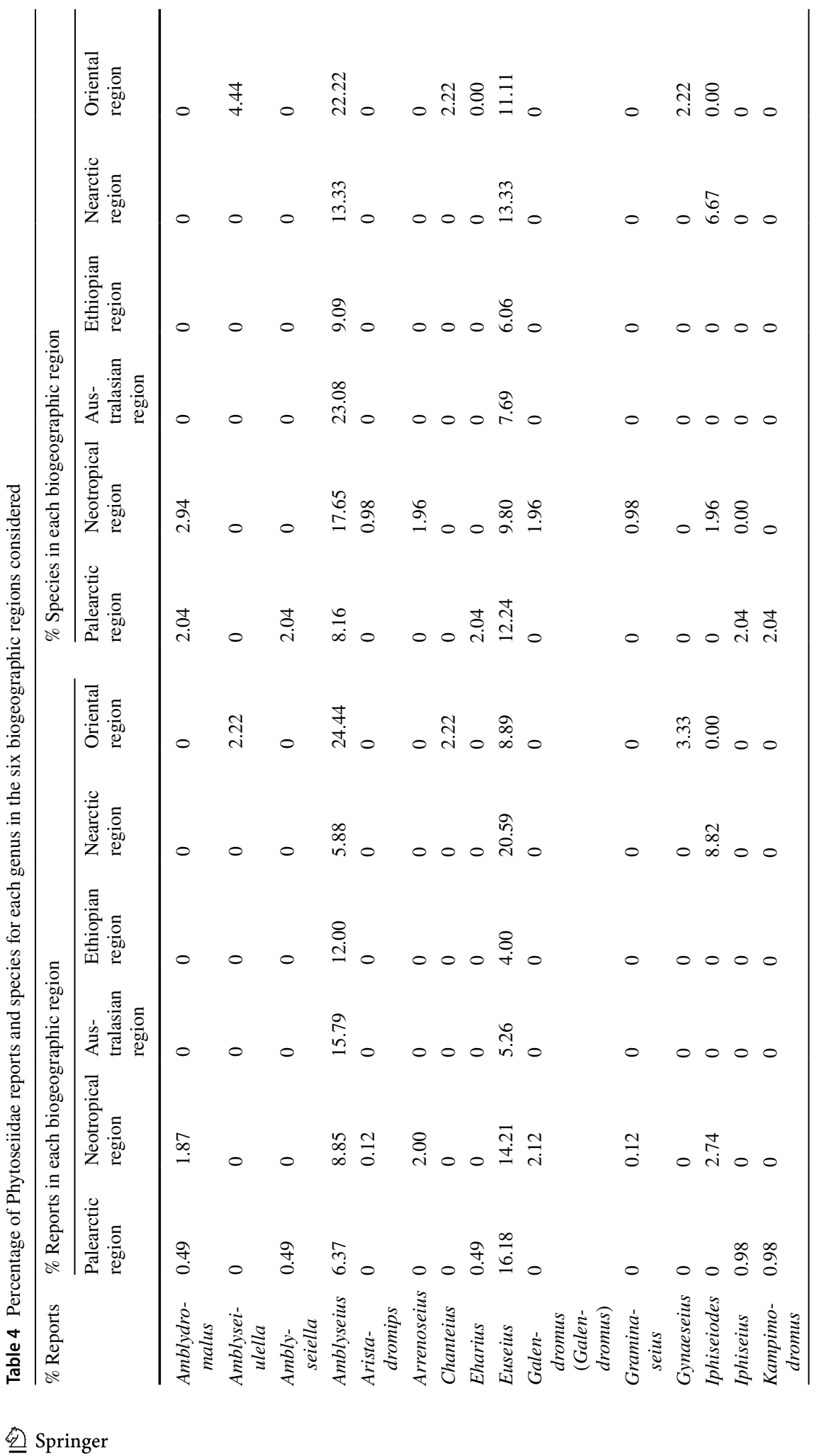




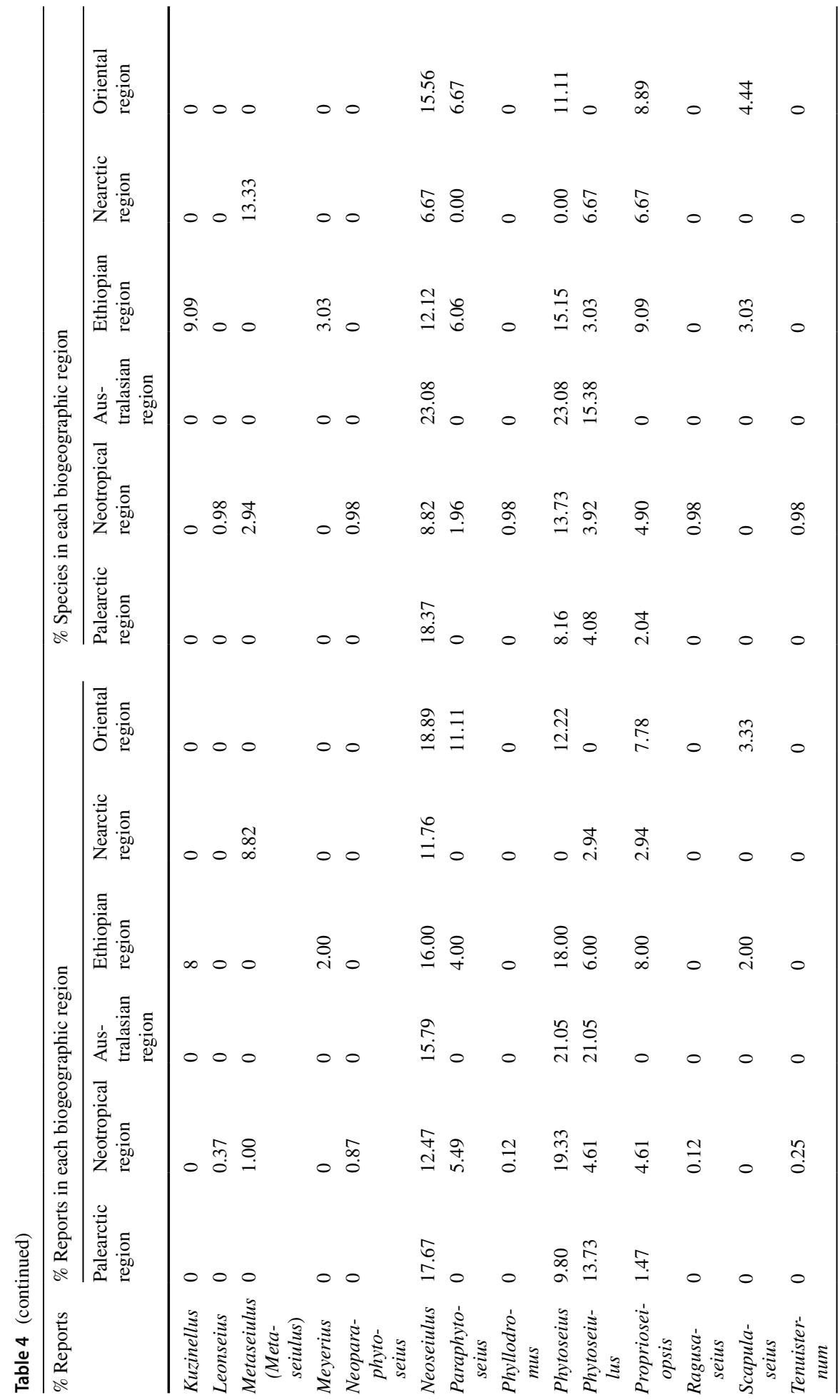




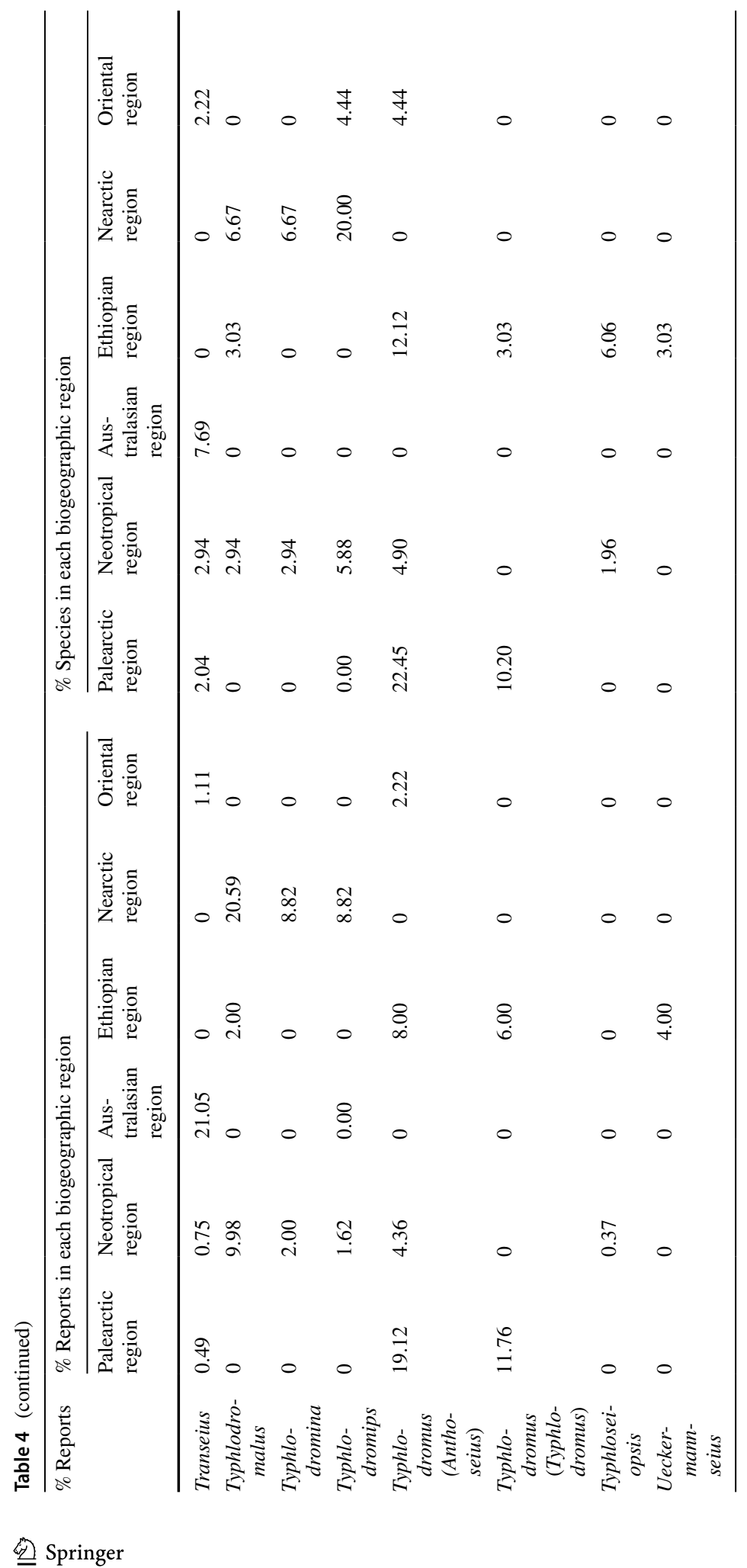




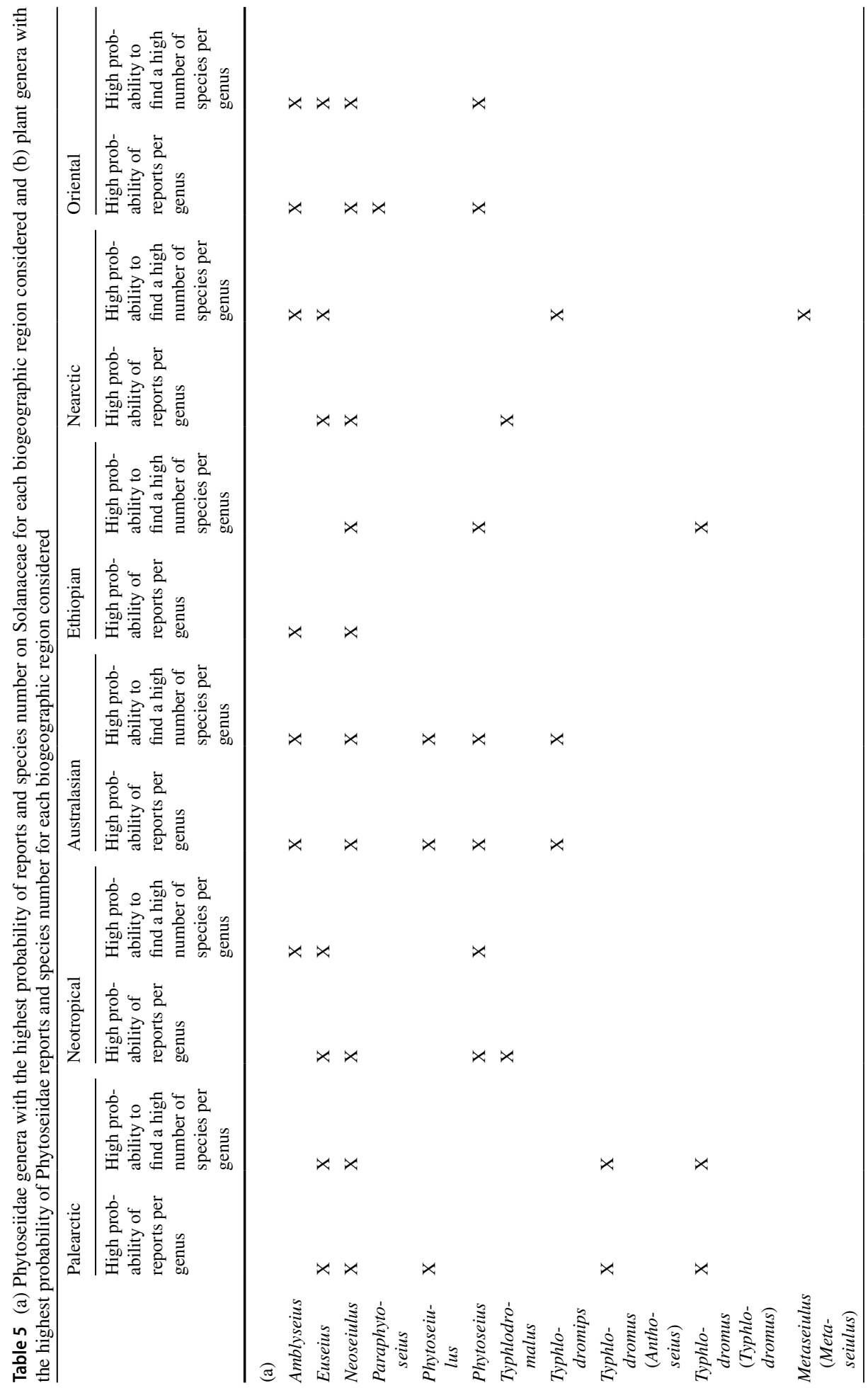




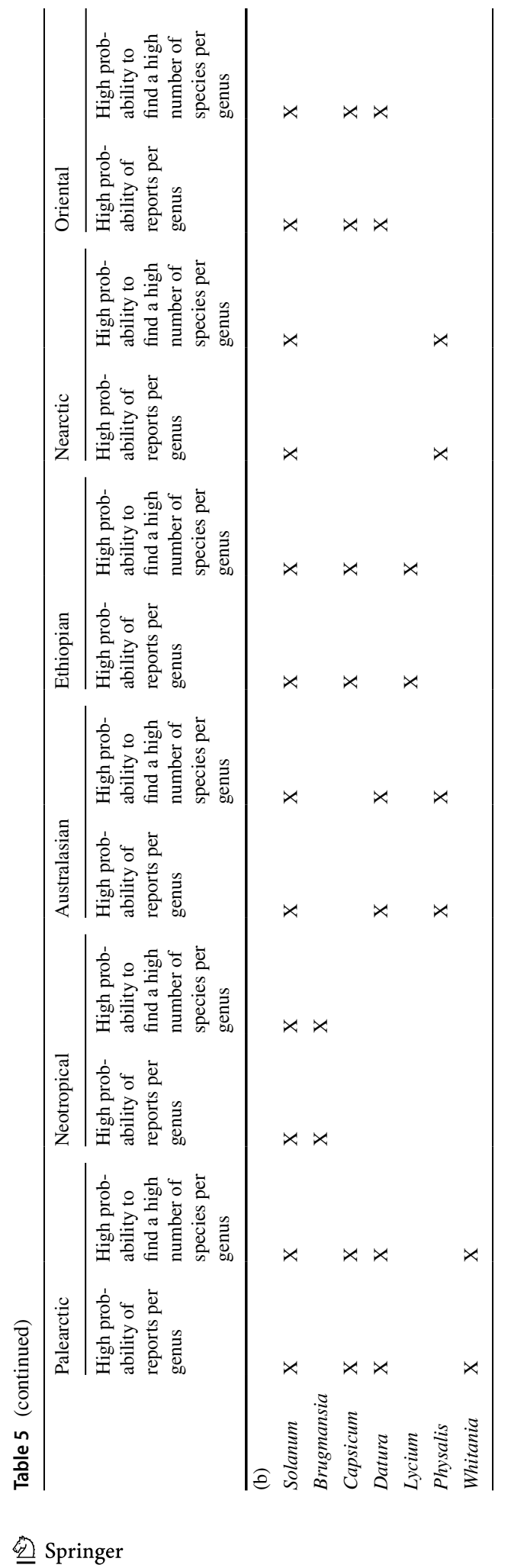


highest percentage of species for Amblyseius, Euseius and Phytoseius. For the oriental region, the highest percentage of reports is observed for the genera Amblyseius, Neoseiulus, Paraphytoseius and Phytoseius and the highest percentage of species for Amblyseius, Euseius, Neoseiulus and Phytoseius. For the Australasian region, the highest percentage of reports is observed for the genera Amblyseius, Neoseiulus, Phytoseius, Typhlodromips and Phytoseiulus and the highest percentage of species for the same genera except Typhlodromips. For the Ethiopian region, the highest percentage of reports is observed for the genera Amblyseius and Neoseiulus and the highest percentage of species for Neoseiulus, Phytoseius and T. (Anthoseius). Finally, for the Nearctic region, the highest percentage of reports is observed for the genera Euseius, Neoseiulus and Typhlodromalus and the highest percentage of species for Euseius, Amblyseius, Metaseiulus (Metaseiulus) and Typhlodromips. These elements can help to model the probability to report Phytoseiidae species of one specific genus in a given area. These results are summarised in the Table 5.

\section{Overview of Phytoseiidae occurrence and Solanaceae plants}

The number of reports of Phytoseiidae on the 99 Solanaceae species globally is low. Phytoseiidae have been reported once on 29 plant species and fewer than 10 reports are observed for 69 plants (i.e., $70 \%$ of the plants considered). The plant species from which Phytoseiidae are the most reported are Solanum paniculatum (136 reports), Solanum americanum (75 reports), S. nigrum (64 reports), S. melongena (111 reports), S. lycopersicum (58 reports) and Solanum sp. (56 reports) (Supplementary file 4).

The number of Phytoseiidae species retrieved per plant species is usually low (33 Solanaceae species with one Phytoseiidae species and 62 Solanaceae with fewer than five Phytoseiidae species). The plant species with the highest number of Phytoseiidae species are S. lycopersicum (39 species), S. americanum (32 species), S. melongena (56 species), $S$. nigrum (29 species), S. paniculatum (28 species), C. annuum (24 species) and Solanum sp. (38 species). Those results suggest that a few plants are favourable to Phytoseiidae. However, the sampling effort is certainly not similar for all the plants considered. Among the plants with the highest number of reports, three are cultivated and some (e.g., S. nigrum) are weeds. A positive linear correlation $\left(\mathrm{R}^{2}=0.76, P<0.01\right)$ is observed between the number of Phytoseiidae reports and the number of species of Phytoseiidae on each plant species, suggesting that the more reports from a specific plant, the higher the number of Phytoseiidae species retrieved.

Among the 16 Solanaceae genera where Phytoseiidae have been reported, five are characterised by a low number of reports ( $<10$ reports: Acnistus, Aureliana, Brunfelsia, Petunia and Salpichroa) (Table 6). For the genera Lycium, Nicandra, Physalis, Vassobia and Withania, the number of reports ranges between 10 and 30. The Solanaceae genera with the most Phytoseiidae species and genera reported are Solanum (800 reports; 32 genera, 165 species), Capsicum (88 reports; 17 genera, 55 species), Datura (55 reports; 15 genera, 36 spe.cies), Brugmansia (54 reports; 13 genera, 24 species), Cestrum (43 reports; 11 genera, 21 species) and Nicotiana (43 reports; 10 genera, 20 species). Solanum and Capsicum contain cultivated species but not the others. Within these two genera, 58, 111 and 28 reports correspond to the cultivated plants tomato, eggplant and pepper, respectively - in total, 169 reports among the 800 recorded for the genus Solanum, and 28 among the 88 recorded for the genus Capsicum. This suggests that the high number of reports in the genera Solanum and Capsicum is not only due to the fact that surveys were carried out on cultivated plants. 


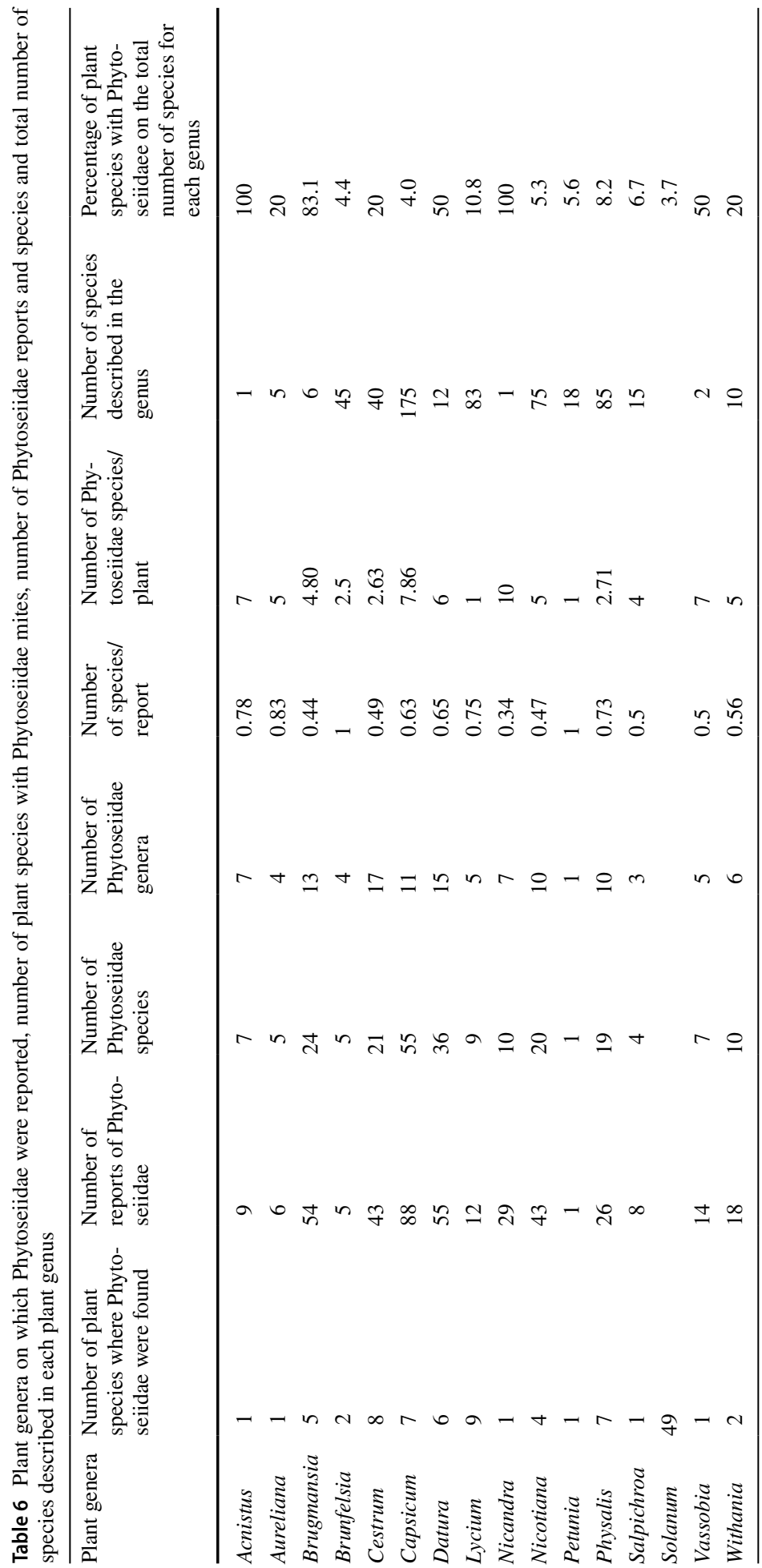


A strong linear correlation is found between the number of reports and the number of genera of Phytoseiidae colonising each plant genus $\left(\mathrm{R}^{2}=0.73, P<0.01\right)$, suggesting that the more reports on a plant genus, the higher the probability to retrieve a high number of Phytoseiidae genera.

A strong linear correlation is also observed between the number of reports and the total number of plant species described in each genus $\left(\mathrm{R}^{2}=0.97, P<0.01\right)$. Excluding the genus Solanum (800 reports, 1,300 species described - disproportionately high numbers that might distort the results), the correlation is still significant but much weaker $\left(\mathrm{R}^{2}=0.33\right.$, $P=0.02$ ), suggesting that the number of reports depends on the number of species described in a plant genus (Supplementary file 5a, b).

The number of plant species on which Phytoseiidae were retrieved is strongly correlated with the total number of plant species in a genus $\left(\mathrm{R}^{2}=0.96, P<0.01\right)$. When excluding the genus Solanum, this correlation is less strong $\left(\mathrm{R}^{2}=0.41, P=0.009\right)$, suggesting that the number of plant species colonised by Phytoseiidae in a Solanaceae genus depends on the number of species described in this genus (Supplementary file $5 \mathrm{c}, \mathrm{d}$ ).

Considering the plant genera with the highest occurrence / report, no particular phytoseiid genus seems to be associated with a particular plant genus, indicating no specialisation pattern between Phytoseiidae and plant genera (Table 7). The genera Amblyseius, Neoseiulus, Euseius and Phytoseius are the most reported. Amblyseius, Neoseiulus and Euseius are reported on 12,12 and 11 genera of Solanaceae, respectively. Altough the genus Phytoseius has the highest number of reports, species of this genus are only retrieved on seven Solanaceae genera. On the opposite, despite a lower number of reports, species of Typhlodromus (Anthoseius) and Phytoseiulus are retrieved on a quite high number of genera (10 and 11, respectively). The same applies, to a lesser extend, for the genera Typhlodromalus ( 87 reports on 7 genera), Typhlodromips (24 records on 8 genera) and Proprioseiopsis (51 reports on 8 genera). It is also interesting to note the relative high number of reports (53) of the genus Paraphytoseius on only two plant genera: Solanum (52 reports) and Datura (1 report).

\section{Phytoseiidae, Solanaceae and biogeographic regions}

Among the 99 Solanaceae plants on which Phytoseiidae were sampled, 74 occur only in one region-48 in the Neotropical region, 11 in the Palearctic region, five in the Ethiopian region, four in the Nearctic region, and six in the Oriental region. One species occurs in all six regions (S. melongena) and four occur in five regions (Capsicum sp., Datura sp., $S$. lycopersicum, Solanum sp.). The highest diversity of species (70) and genera (13) of Solanaceae plants is observed in the Neotropical region, followed by the Palearctic ( 24 species, 7 genera) and the Oriental region (18 species, 6 genera). For all the regions, the highest number of reports is observed in the genus Solanum.

In the Neotropical region, the genera Brugmansia, Capsicum, Cestrum, Datura, Nican$d r a$ and Nicotiana are characterised by a high percentage of Phytoseiidae species. The percentage of records in those genera is in proportion much lower, suggesting that the colonisation of these genera was recorded only a few times for many mite species. Despite a low number of species in the genus Brugmansia, Phytoseiidae have been observed on five of the six species described, and the number of mite species and genera is among the highest (23 species, 13 genera) (Table 8). In the Palearctic region, the highest percentages of species and reports are observed on Capsicum, Datura and Whitania. In the Australasian region, the highest values are observed on Capsicum, Datura and Physalis. It is interesting 


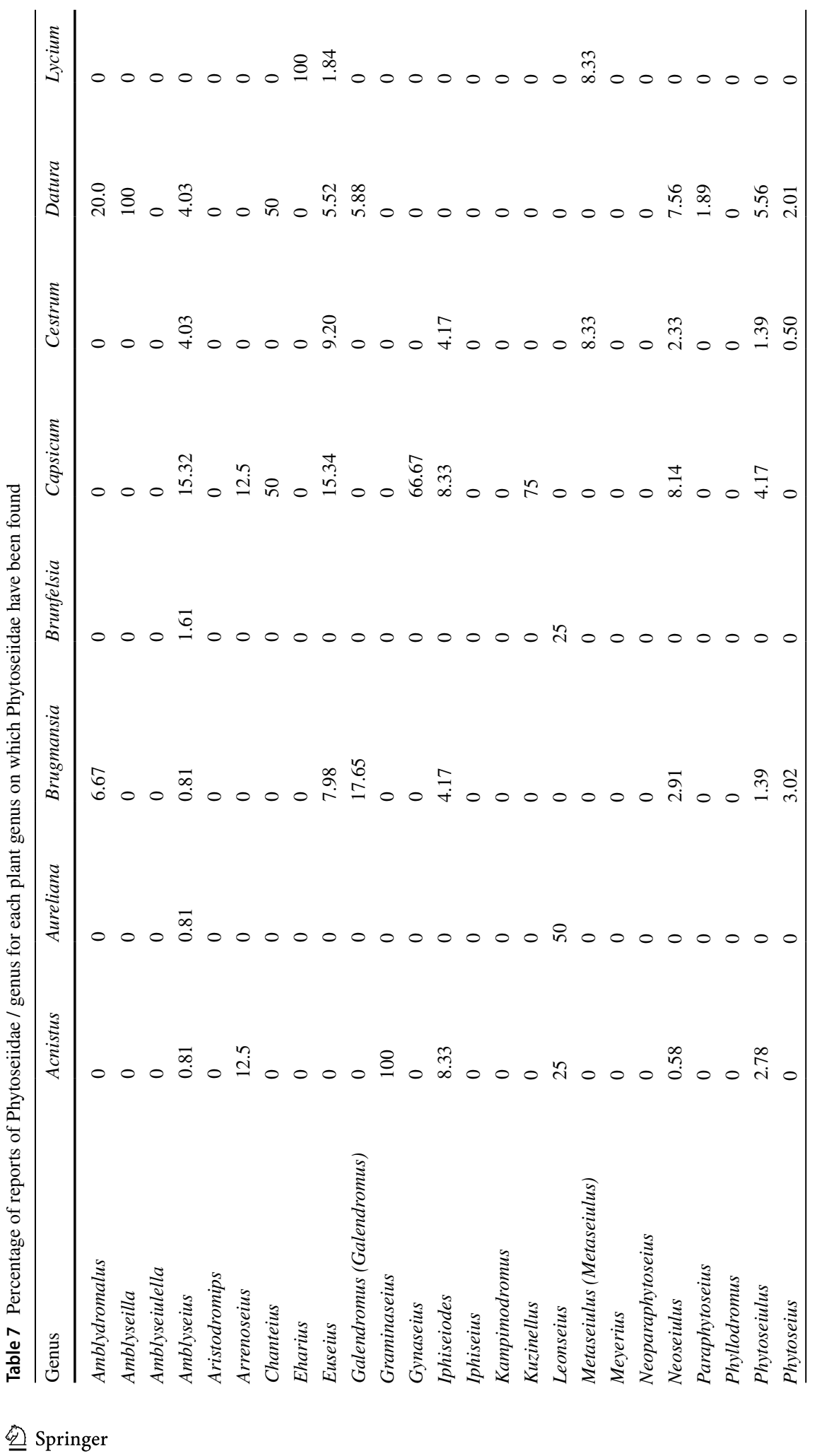




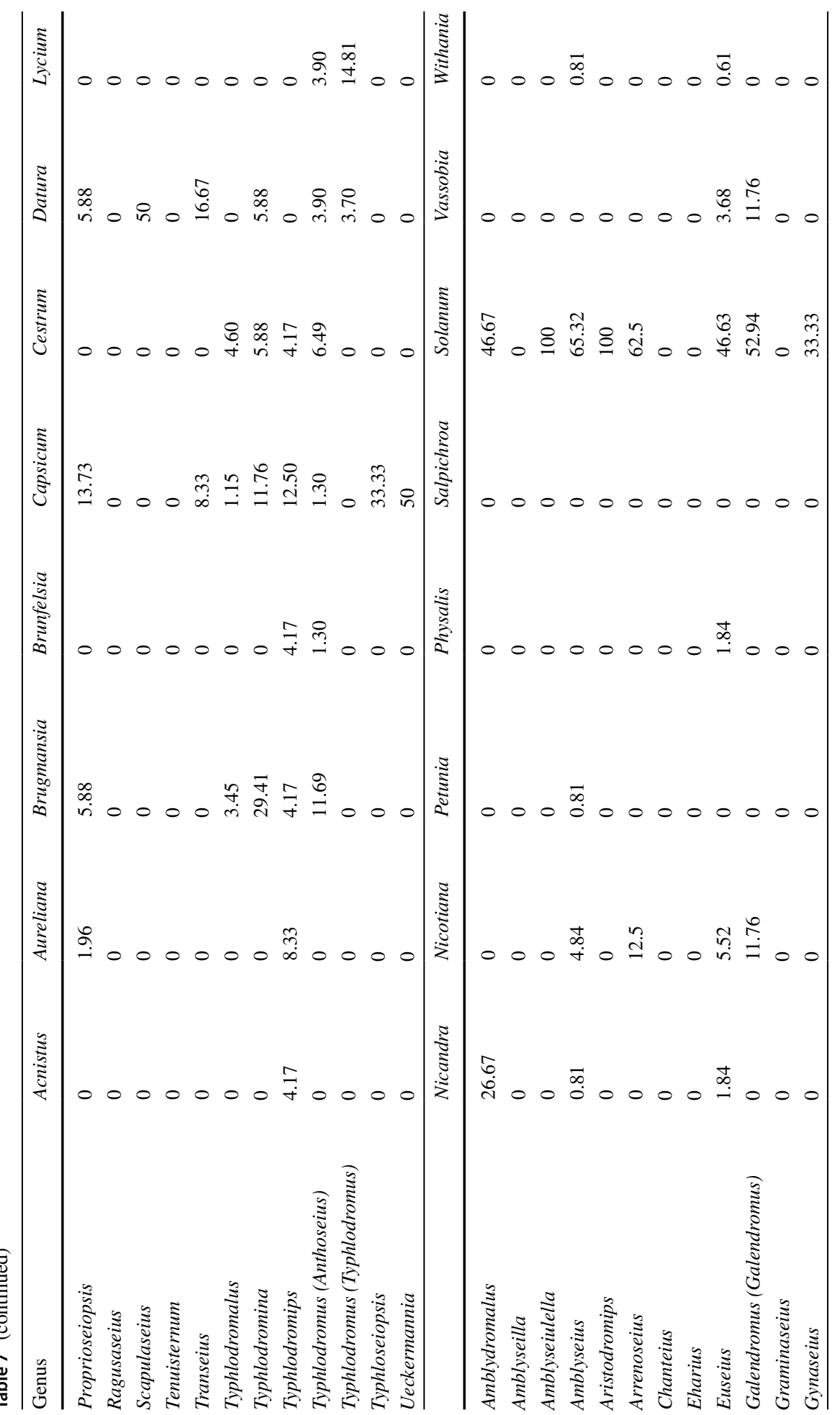




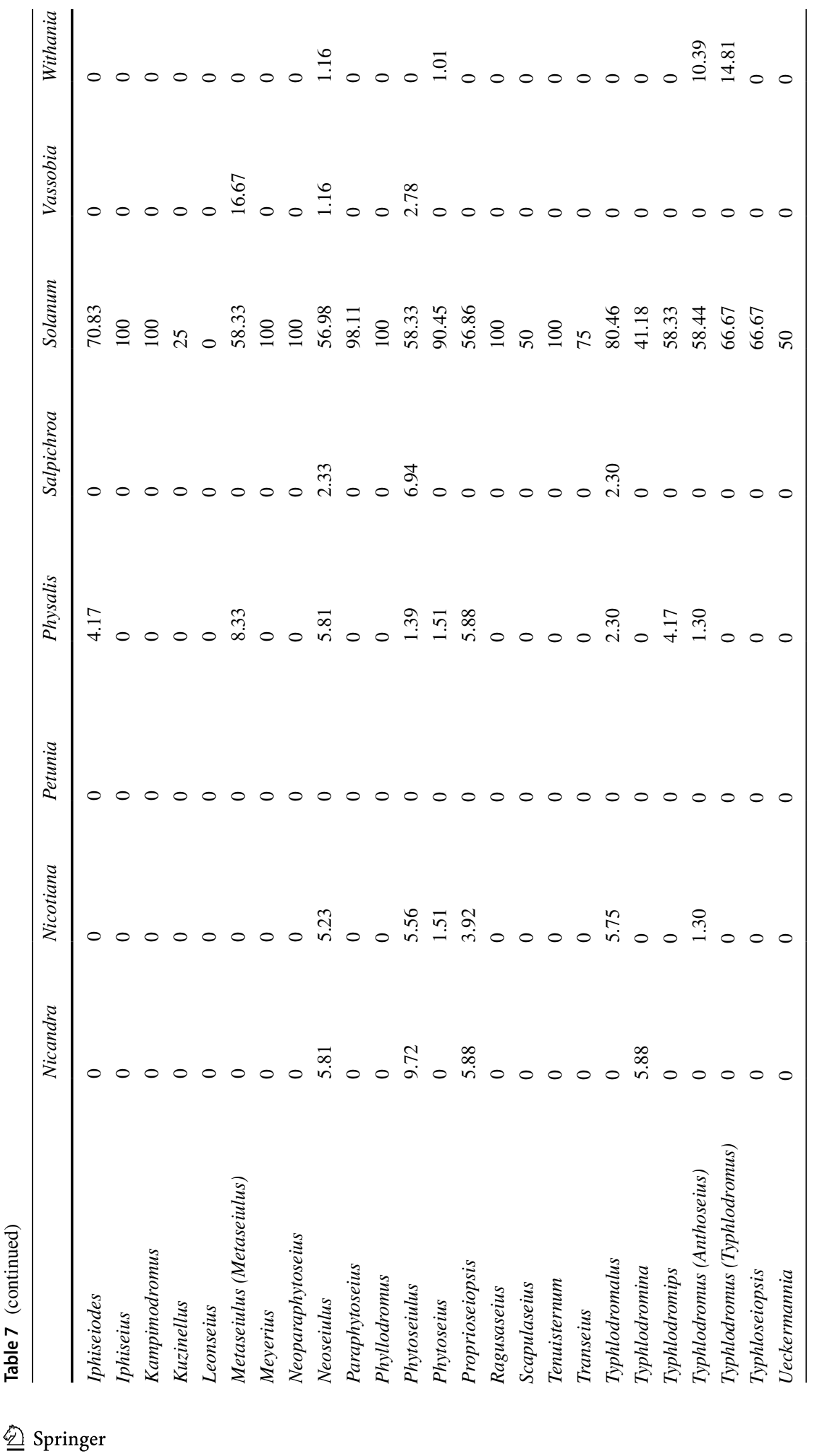




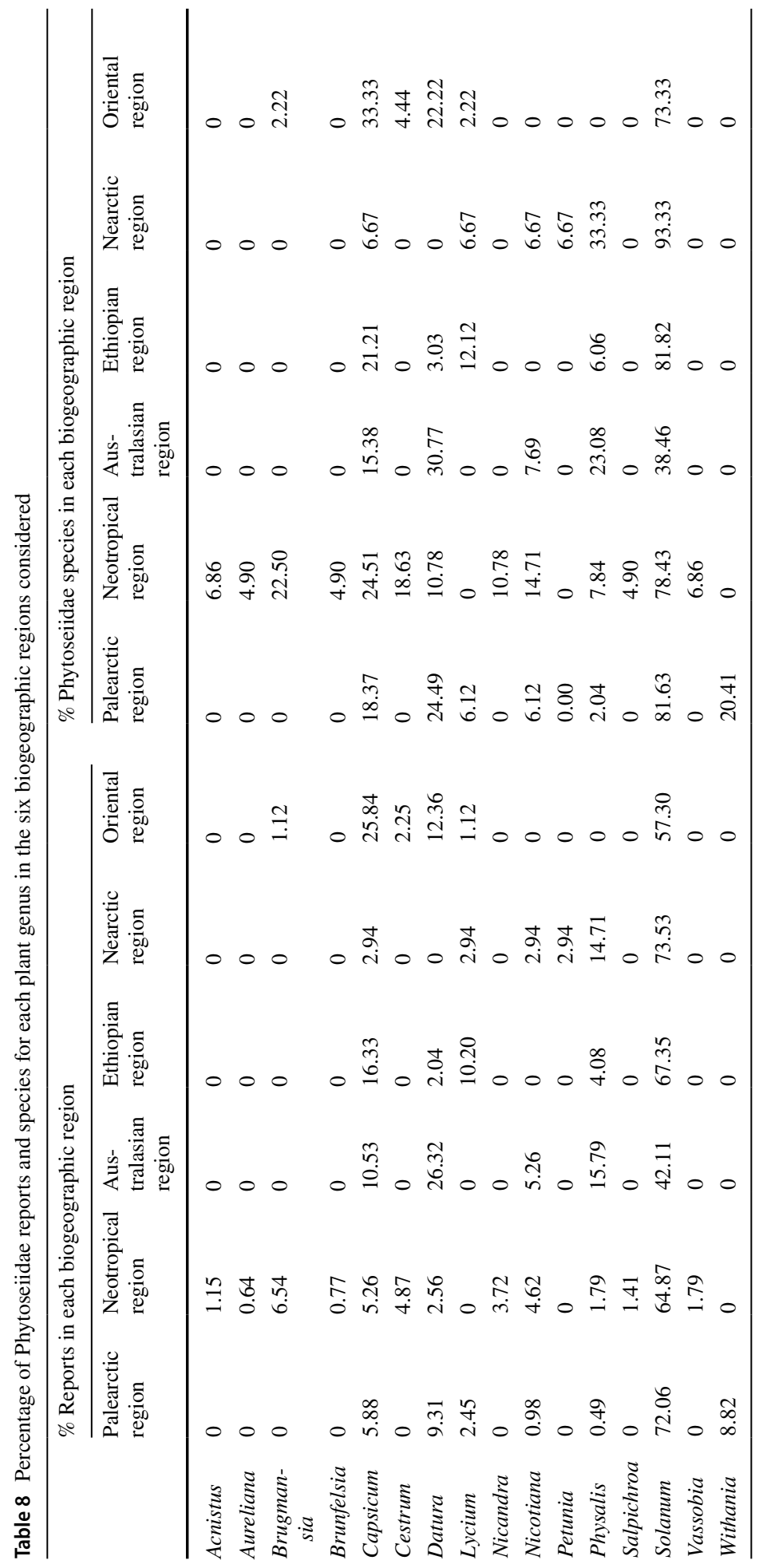


to note that for this region both the diversity and the report percentage on Solanum is lower than in the other areas. In the Ethiopian region, the highest percentages of reports and species are retrieved on Capsicum and Lycium. In the Nearctic region, the highest values are observed for the genus Physalis. Finally, for the Oriental region, the highest percentage of reports and species are observed on Datura and Capsicum. Table 5a shows a synthesis of these results, indicating the plant genera with the highest probability to be colonised by Phytoseiidae species.

It is interesting to note the prevalence of the genera Amblyseius, Neoseiulus, Euseius and Typhlodromus (Anthoseius) on several plant genera (not necessarily the same) and the prevalence of Phytoseius only for species of the genus Solanum and to a lesser extent for species of the genus Typhlodromalus on Salpichroa. Typhlodromus (Anthoseius) species are often recorded on the genus Withania, species of Euseius on the genera Vassobia and Cestrum, species of Amblyseius on the genus Brunfesia and species of Neoseiulus on the genera Physalis, Nicandra and Salpichroa. Despite a high number of records, the proportion of the reports of Phytoseiulus is only high in a few plant genera (e.g., Salpichroa and Nicandra).

In the Australasian region, the two plants with the highest number of Phytoseiidae species and reports are Datura sp. and S. lycopersicum. In the Ethiopian region, the most favourable plant species (7 species of Phytoseiidae, 7 reports) is Solanum auriculatum. In the Nearctic region, this is $S$. americanum (15 reports, 7 Phytoseiidae species). In the Neotropical region, the two plant species most frequently occupied by Phytoseiidae $(>60$ reports) are $S$. americanum and $S$. paniculatum. In this same region, four species harbour more than 20 species of Phytoseiidae (of the 102 retrieved in this region): S. lycopersicum, $S$. americanum, $S$. melongena and $S$. paniculatum. In the Oriental region, the two most occupied plant species (reports and numbers of Phytoseiidae species) are S. melongena and Capsicum sp., whereas in the Palearctic region, it is S. nigrum, S. lycopersicum, S. melongena and D. stramonium. In (almost) all the biogeographic regions, plants with the highest number of species and reports correspond to cultivated plants, especially pepper, tomato and eggplant, and some weeds (e.g., S. nigrum in the Palearctic area); however, this is not totally true for the Neotropical and Ethiopian regions.

\section{Diversity of Phytoseiidae mites on Solanaceae and evolution}

Phytoseiidae retrieved on Solanaceae belong to 37 genera on the 98 in this family. Furthermore, the highest numbers of species and reports are concentrated in four genera: Amblyseius, Euseius, Neoseiulus and Phytoseius (more than 100 reports, 105 species) and to a lesser extend (with more than 70 reports) in the genera Phytoseiulus, Typhlodromalus and Typhlodromus (Anthoseius) (74\% of reports and 62\% of species retrieved). Five of them belong to the sub-family Amblyseiinae, one to Typhlodrominae and one to Phytoseiinae. These genera are not evolutionarily related, as they belong to different sub-families and tribes. Furthermore, these genera are the most diverse within the family Phytoseiidae (except for Typhlodromalus and Phytoseiulus) and only a small share of the species of these genera are found on Solanaceae plants [7.8\% for Amblyseius, 11.9\% for Euseius, $6.2 \%$ for Neoseiulus, $12.4 \%$ for Phytoseius, $16 \%$ for Typhlodromalus and 5.0\% for Typhlodromus (Anthoseius)] (Table 2). An exception is Phytoseiulus for which the four species have been reported on Solanaceae.

No clear adaptation for a region is observed, as high diversity and reports are globally observed for the same genera for all the regions, suggesting local adaptation to 
Solanaceae species in these genera. However, it is worth to note some 'specialisation' for the genera Typhlodromalus in the Neotropical region and Typhlodromus (Anthoseius) in the Palearctic region. It is also interesting to note that high percentages of species of a single genus on Solanaceae have mainly been observed for genera endemic to the Neotropical region (i.e., Leonseius, Neoparaphytoseius, Phyllodromus, Ragusaseius, Tenuisternum, Typhlodromina).

All these data suggest that adaptation to live on Solanaceae (i) has appeared several times separately during evolution, (ii) probably ancestrally originated from the Neotropical region, and (iii) is recent for most of the genera considered, as not all the species of a genus have these features.

\section{Conclusion}

The first main conclusion of this review is that the presently known Phytoseiidae diversity on Solanaceae only represents a small part of the total biodiversity of this family. The various correlations (between the number of species and reports per Phytoseiidae genus, the number of reports and species per plant genus, the number of Phytoseiidae reported and those described in each genus) show that many more species might be found when enhancing sampling efforts, whatever the biogeographic region considered. However, based on the presently available biodiversity data, it seems that Phytoseiidae are not very frequent on Solanaceae (mainly a low number of reports and a low number of species per phytoseiid genus and plant surveyed).

The Phytoseiidae genera with the highest number of reports are not phylogenetically related and at present no evolutionary scenario can explain the Phytoseiidae diversification on Solanaceae. It seems that adaptation to solanaceous plants occurred several times during the course of evolution and in all biogeographic regions except the Neotropical region this adaptation is recent. The Neotropical area is particular, as it contains the highest number of reports of Phytoseiidae species, Phytoseiidae genera and Solanacae plants surveyed, probably because of the high diversity of these plants in this region; therefore, it is assumed to be the centre of origin of the family.

Based on the present analyses, we have formulated some probability to retrieve Phytoseiidae species per biogeographic area and plant genus. These probabilities are partly verified using the survey carried out in the South of France (Palearctic region) where, as expected, the highest numbers of species and reports were observed for Euseius, Phytoseiulus and Typhlodromus (Anthoseius). One genus, Typhlodromus (Typhlodromus), expected to be found, was lacking, probably because this prediction was based on the high reports of $T$. (T.) athiasae in the Palearctic area, whereas this species is not present in France. Thus, the elements formulated in Table 5 can help to assess the Phytoseiidae genera and plants with higher probability of Phytoseiidae occurrence in the various regions considered. We expect that this may be useful when searching for new predators for biological control issues.

Among the Phytoseiidae reported on Solanaceae all over the world, only a few (18) are currently used in biocontrol programs, with the highest number of reports for N. californicus, $P$. persimilis and T. aripo, and to a lesser extend for Amblyseius swirskii Athias-Henriot, E. gallicus and Phytoseius finitimus Ribaga. Some populations of these species might thus be adapted to Solanaceae, as already reported by Ferrero et al. (2014a, b), who found differences in predation ability and Solanaceae adaptation between different populations 
of Phytoseiulus longipes Evans. This confirms that adaptation to Solanaceae might be a recent event and calls for searching and testing of wild populations of these species, and not just of commercialised strains.

It is interesting to note that, except $N$. californicus and $P$. persimilis, no commercialised or phytoseiid species retrieved on Solanaceae are studied, suggesting that they might be good candidates for biological control applications in Solanaceae crops - for example, $E$. stipulatus, T. (A.) recki, P. finitimus, T. (T.) athiasae in the Palearctic region, and P. guianensis, E. concordis, $T$. peregrinus and $P$. orientalis in the Neotropical region. For the other regions, some species could be pointed at, although the number of reports was much lower than in the Palearctic and Neotropical areas-for example, T. montdorensis in the Australasian region, $P$. amba in the Ethiopian region, T. peregrinus and Euseius mesembrinus (Dean) in the Nearctic region, and P. bhadrakaliensis, P. kapuri and N. longispinosus in the Oriental area.

Finally, no particular relationship was observed between Solanaceae plants and Phytoseiidae diversity. Most Phytoseiidae species and reports were found on plants of the genus Solanum, which is also the most diverse within the family Solanaceae, worldwide. However, other plant genera seem to be also favourable to Phytoseiidae, especially the genus Brugmansia in the Neotropical region, which is mainly colonised by the genera Euseius and Typhlodromus (Anthoseius). Some species in each of the geographic regions seem to be favourable to Phytoseiidae species: $S$. auriculatum and to a lesser extend Capsicum sp. and Lycium cinereum in the Ethiopian region, $S$. americanum and Capsicum sp. in the Neartic region, Brugmansia arborea, S. lycopersicum, Nicandra physaloides, N. glauca, Solanum caricaefolium in the Neotropical region, C. annuum and Capsicum sp. in the Oriental region, and $S$. lycopersicum and $C$. annuum in the Palearctic region. Some of these plants are cultivated species (tomato and pepper) but not all of them. The most favourable plants in Ethiopian and Neotropical areas are not cultivated plants. Furthermore it is interesting to note a low number of reports for potatoes. One continuation of this work would be to determine the relationships between traits of plants and Phytoseiidae, to better understand why some Phytoseiidae species are most reported on some Solanaceae plants, in order to search for new biocontrol agents adapted to cultivated Solanaceae plants for both biocontrol and breeding applications. Relevant plant traits would be, e.g., morphological traits (such as leaf and stem trichomes) and biochemical traits (such as alkaloids). For biological control issues, in further surveys it would also be worthwhile to include other predatory mites, such as species of the genus Homeopronematus (Trombiformes: Iolinidae), based on some interesting findings by Kawai and Jaque (2004).

Acknowledgements We thank the French national program (Ecophyto-Project ACAROSOL) that granted in part the surveys carried out. We also thank the two referees for their comments and associated improvements of the manuscript.

\section{Compliance with ethical standards}

Conflict of interest The authors declare no conflict of interest.

\section{References}

Amitai S, Swirski E (1978) A new genus and new records of phytoseiid mites (Mesostigmata: Phytoseiidae) from Israel. Isr J Entom 12:123-143 
Baraja MJ, Montalban C (1996) Lucha integrada en tomate de primavera bajo plástico. Phytoma España $76: 18-24$

Calvitti M, Tsolakis H (1992) Acari predatori fitoseidi presenti su alcune colture erbacee nel Lazio. Redia 75:529-535

Chant DA, McMurtry JA (2007) Illustrated keys and diagnoses for the genera and sub-genera of the Phytoseiidae of the World. Indira Publishing House, West Bloomfield, p 220

Darlington PJ (1957) Zoogeography: the geographical distribution of animals. Wiley, New York, London

Demite PR, McMurtry JA, Moraes GJ (2014) Phytoseiidae Database: a website for taxonomic and distributional information on phytoseiid mites (Acari). Zootaxa 3795:571-577

Demite PR, Moraes GJ de, McMurtry JA, Denmark HA, Castilho RC 2019. Phytoseiidae Database. Available at: www.lea.esalq.usp.br/phytoseiidae. Accessed 15 Aug 2019

Döker I, Stathakis TI, Kazak C, Karut K, Papadoulis GT (2014) Four new records and two new species of Phytoseiidae (Acari: Mesostigmata) from Turkey, with a key to the Turkish species. Zootaxa 3827:331-342

Duso C (1992) Role of Amblyseius aberrans (Oud.), Typhlodromus pyri Scheuten and Amblyseius andersoni (Chant) (Acari, Phytoseiidae) in vineyards. J Appl Entomol 114:455-462. https://doi. org/10.1111/j.1439-0418.1992.tb01151.x

Ferrero M, Tixier M-S, Kreiter S (2014a) From specificity to specialisation. I. Comparative life histories of three populations of Phytoseiulus longipes Evans (Acari, Mesostigmata, Phytoseiidae) depending on prey species and plant supports. Exp Appl Acarol 62:313-324

Ferrero M, Tixier M-S, Kreiter S (2014b) From specificity to specialisation. II. Choice tests and attractiveness of different prey species, prey stages and plant supports for two populations of Phytoseiulus longipes Evans [Acari, Mesostigmata, Phytoseiidae]. Exp Appl Acarol 62:325-335

Fiaboe KKM, Gondim MGC Jr, de Moraes GJ, Ogol CKPO, Knapp M (2007) Surveys for natural enemies of the tomato red spider mite Tetranychus evansi (Acari: Tetranychidae) in northeastern and southeastern Brazil. Zootaxa 1395:33-58

Gerson U, Smiley RL, Ochoa T (2003) Mites (Acari) for pest control. Blackwell Science, Oxford, p 539

Guanilo AD, de Moraes GJ, Knapp M (2008a) Phytoseiid mites (Acari: Phytoseiidae) of the subfamily Amblyseiinae muma from Peru, with description of four new species. Zootaxa 1880:1-47

Guanilo AD, de Moraes GJ, Toledo S, Knapp M (2008b) Phytoseiid mites (Acari: Phytoseiidae) from Argentina, with description of a new species. Zootaxa 1884:1-35

Kanouh M, Tixier M-S, Okassa M, Kreiter S (2010) Phylogenetic and biogeographic analysis of the genus Phytoseiulus (Acari: Phytoseiidae). Zool Scr 39:450-461. https://doi.org/10.111 1/j.1463-6409.2010.00439.x

Karban R, English-Loeb G, Walker MA, Thaler J (1995) Abundance of phytoseiid mites on Vitis species: effects of leaf hairs, domatia, prey abundance and plant phylogeny. Exp Appl Acarol 19:189-197. https ://doi.org/10.1007/BF00130822

Kawai A, Jaque MM (2004) Population dynamics of tomato russet mite, Aculops lycopersici (Massee) and its natural enemy, Homeopronematus anconai (Baker). J Agr Res Quartely 38(3):161-166

Kennedy GG (2003) Tomato, pest, parasitoids, and predators: tritrophic interactions involving the genus Lycopersicon. Ann Rev Entomol 48:51-72

Kolodochka LA, Omeri ID (2007) Species Diversity and distribution of plant-inhabiting phytoseiid mites (Parasitiformes, Phytoseiidae) in Kaniv Reserve. Vest zool 41(1):35-46

Kreiter S, Tixier M-S, Auger P, Muckensturm N, Sentenac G, Doublet B, Weber M (2000) Phytoseiid mites of vineyards in France (Acari: Phytoseiidae). Acarologia 41(1-2):77-96

Kreiter S, Auger P, Lebdi Grissa K, Tixier M-S, Chermiti B, Dali M (2002) Plant inhabiting mites (Acari: Prostigmata \& Mesostigmata) of some Northern Tunisian crops. Acarologia 42(4):389-402

Kreiter S, Lebdi Grissa K, Chabaan S, Chatti A, Tixier M-S, Auger P, Chermiti B, Ksantini M, Khoualdia O (2010) Phytoseiid mites (Acari: Mesostigmata) from Tunisia: catalogue, biogeography and key for identification. Tun J Plant Prot 5:151-178

Kumral NA, Cobanoglu S (2015a) The potential of the nightshade plants (Solanaceae) as reservoir plants for pest and predatory mites. Türkish entomol derg 39(1):91-108

Kumral NA, Cobanoglu S (2015b) A reservoir weed for mites: Datura stramonium L. (Solanaceae) in the vicinity of cultivated solanaceous plants in Turkey. Int J Acarol 41:563-573. https://doi. org/10.1080/01647954.2015.1084043

McMurtry JA, Bounfour M (1989) Phytoseiid mites of Morocco, with descriptions of two new species and notes on the genera Kuzinellus, Typhloctonus and Typhlodromus (Acari: Phytoseiidae). Acarologia 30:13-24

McMurtry JA, Croft BA (1997) Life-styles of phytoseiid mites and their roles in biological control. Ann Rev Entomol 42:291-321 
McMurtry JA, De Moraes GJ, Sourasso NF (2013) Revision of the lifestyles of phytoseiid mites (Acari: Phytoseiidae) and implications for biological control strategies. Syst Appl Acarol 18(4):297-320

Okassa M, Kreiter S, Guichou S, Tixier M-S (2011) Molecular and morphological boundaries of the predatory mite Neoseiulus californicus (McGregor) (Acari: Phytoseiidae). Biol J Linn Soc 104:393-406

Olmstead GH (2013) Phylogeny and biogeography in Solanaceae, Verbenaceae and Bignoniaceae: a comparison of continental and intercontinental diversification patterns. Bot J Linn Soc 171:80-102

Papadoulis GTh, Emmanouel NG, Kapaxidi EV (2009) Phytoseiidae of Greece and Cyprus (Acari: Mesostigmata). Indira Publishing House, West Bloomfield, p 200

Papaioannou-Souliotis P, Ragusa di Chiara S, Tsolakis C (1994) Phytophagous mites and their predators observed on cultivated plants in Greece during 1975-1990. Annales Institut Phytopathologique Benaki N.S. 17:35-86

Sahraoui H, Lebdi-Grissa K, Kreiter S, Douin M, Tixier M-S (2012) Phytoseiid mites (Acari: Mesostigmata) of Tunisian Citrus orchards. Acarologia 52:433-452

Sanchez JA, Contreras J, Lacasa A, Llorca M (1995) Datos preliminares sobre la utilización de Orius laevigatus (Fieber) en el control de Frankliniella occidentalis (Pergande) en pimiento en invernadero. Phytoma España 68:32-38

Sekeroglu E, Kazak C (1993) First record of Phytoseiulus persimilis (Acari: Phytoseiidae) in Turkey. Entomophaga 38(3):343-345

Simmons AT, Gurr GM (2005) Trichomes of Lycopersicon species and their hybrids: effects on pests and natural enemies. Agr For Entomol 7:265-276

Swirski E, Amitai S (1984) Notes on phytoseiid mites (Mesostigmata: Phytoseiidae) from the Mediterranean littoral zone of Israel, with a description of a new species of Typhloctonus. Isr J Entomol 18:71-82

StatSoft France (2010) STATISTICA (logiciel d'analyse des données), version 9.1. https://www.statsoft.fr.

Swirski E, Amitai S (1997) Annotated list of phytoseiid mites (Mesostigmata: Phytoseiidae) in Israel. Isr J Entomol 31:21-46

Tixier M-S, Kreiter S, Moraes GJ (2008) Biogeographic distribution of the mites of the family Phytoseiidae (Acari: Mesostigmata). Biol J Linn Soc 93:845-856

Tixier M-S, Kreiter S, Douin M, Moraes GJ (2012) Rates of description of Phytoseiidae (Acari: Mesostigmata): space, time and body size variations. Biodiv Conser 21:993-1013. https://doi.org/10.1007/ s10531-012-0235-0

Tixier M-S, Baldassar A, Duso C, Kreiter S (2013) Phytoseiidae in European grape (Vitis vinifera L.): bioecological aspects and keys to species (Acari: Mesostigmata). Zootaxa 3721:101-142

Tixier M-S, Lopes I, Blanc G, Dedieu J-L, Kreiter S (2014) Phytoseiidae mites (Acari: Mesostigmata) in French orchards and assessment of their spatial distribution. Acarologia 54(1):97-111

Tixier M-S, Allam L, Douin S, Kreiter S (2016) Phytoseiidae (Acari: Mesostigmata) of Morocco: new records, descriptions of five new species, re-descriptions of two species and key for identification. Zootaxa 4067:501-551

Van Leeuwen T, Vontas J, Tsagkarakou A, Dermauw W, Tirry L (2010) Acaricide resistance mechanisms in the two-spotted spider mite Tetranychus urticae and other important Acari: a review. Insect Biochem Mol Biol 40(8):563-572

Zhang Z-Q (2003) Mites of greenhouses. Identification, biology and control. CABI, London

Publisher's Note Springer Nature remains neutral with regard to jurisdictional claims in published maps and institutional affiliations. 